\title{
時間・空間平均法を用いた筒内流動サイクル変動成分の抽出 および可変フィルタサイズ空間平均法の提案
}

\author{
保木本 聖*1，窪山 達也 ${ }^{* 2}$ ，金子 誠*2，森吉 泰生 ${ }^{* 3}$ \\ 孕石 三太 ${ }^{* 4}$, 渡辺 敬弘 ${ }^{* 4}$, 飯田 実 ${ }^{* 4}$

\section{An extraction of cycle-to-cycle variation of in-cylinder flow using temporal / spatial averaging and a proposal of variable sized spatial filtering} \\ Satoshi HOKIMOTO*1, Tatsuya KUBOYAMA ${ }^{* 2}$, Makoto KANEKO ${ }^{* 2}$, Yasuo MORIYOSHI*3, \\ Santa HARAMIISHI ${ }^{* 4}$, Takahiro WATANABE ${ }^{* 4}$ and Minoru IIDA ${ }^{* 4}$ \\ ${ }^{* 1,}{ }^{* 2}$, ${ }^{*}$ Chiba Univ. Dept. of Mechanical Engineering, Graduate School of Engineering \\ 1-33 Yayoi-cho, Inage-ku, Chiba-shi, Chiba 263-8522, Japan \\ ${ }^{*}$ Engine Research Group, YAMAHA MOTOR CO., LTD. \\ 2500 Shingai, Iwata-shi, Shizuoka 438-8501, Japan
}

Received: 28 June 2018; Revised: 9 October 2018; Accepted: 6 February 2019

\begin{abstract}
Cycle-to-cycle variation (CCV) of in-cylinder flow occurs in internal combustion engines. It is necessary to analyze CCV of flow to separate averaged-flow (as low frequency / low wave number) from turbulence (as high frequency / high wave number), because an averaged flow varies from cycle to cycle. Two averaging methods are used for the extraction of mean component from instantaneous flow. One is temporal-averaging method, the other is spatial-averaging method. In the temporal -averaging method, a fluctuation of flow is captured at fixed point in Eulerian, turbulence is regarded as the high frequency component, and it is removed by a low pass filtering. In the spatial-averaging method, the turbulence in spatial arrangement of flow velocity is directly averaged by using vortex scale as a threshold (e.g. Moving-averaging filter and Gaussian-averaging filter). However, the temporal-averaging and the spatial-averaging have completely different characteristics. Therefore, it is necessary to clarify the difference of filtering characteristics in each averaging filter. In this study, comparisons of averaged flow patterns of temporal-average and spatial-average are carried out. Moreover, variable sized spatial filter which is based on Taylor's frozenturbulence hypothesis is proposed. As a result, variable sized filtering is found close to the filter characteristic of the time average method.
\end{abstract}

Keywords : Internal combustion engine, Cycle-to-cycle variation, High-speed PIV, In-cylinder flow, Temporalaveraging, Spatial-averaging, Flow analysis

\section{1. 緒言}

内燃機関における筒内流動の解析手法として，LDV（Laser Doppler Velocimeter）や熱線流速計を用いた任意定 点データの高速サンプリングによる解析が行われてきたが，レーザやカメラなどの性能向上に伴い，PIV（Particle Image Velocimetry）による面データでも高速サンプリングが可能となってきた．PIV で計測したある時刻の瞬時流 には，時間的・空間的な様々なスケール流れが含まれており，流動解析を簡易化させるため，大規模スケール流 れを形成する成分（平均流）と渦などの小さなスケールの成分（乱れ）の二つに分けて考えることが多い.内燃

No.18-00278 [DOI:10.1299/transjsme.18-00278], J-STAGE Advance Publication date : 14 February, 2019

${ }^{* 1}$ 正員, 千葉大学大学院（广263-8522 千葉県千葉市稲毛区弥生町 1-33)

*2 正員, 千葉大学

*3 正員, フェロー, 千葉大学

*4 ヤマ八発動機（株）（广438-8501 静岡県磐田市新貝 2500）

E-mail of corresponding author: s_hokimoto_0726@yahoo.co.jp 
Hokimoto, Kuboyama, Kaneko, Moriyoshi, Haramiishi, Watanabe and Iida, Transactions of the JSME (in Japanese), Vol.85, No.871 (2019)

機関の筒内流動サイクル変動の解析を行う場合, 複雑な乱れを含んだ瞬時流から平均化処理により平均流の成分 を取り出し, 平均流のサイクル変動を解析するのが一般的である.

サイクル変動の無い流れ場における瞬時流速 $u$ は, レイノルズ分解により式(1)に示すように時間平均流速 $\bar{U}$ と乱れ $u^{\prime}$ の和で定義される（Tennekes and Lumley, 1972）。これは運動方程式やナビエ・ストークス方程式と同様 に時間を変数とした時間に関する式である. また式(1)はアンサンブル平均流速 $\langle U\rangle$ と乱れ $u^{\prime}$ の和でも定義され る. 時間平均＝アンサンブル平均となるエルゴードの仮説が成り立つと仮定すると, 式(1)のように定義され, 平 均流がサイクル変動するとすれば, 式(2)に示す通りとなる. 従って, 本研究では式(2)に示す関係から時間平均流 速とアンサンブル平均流速の差分をサイクル変動成分 $u_{c}$ と定義した.

$$
\begin{array}{ll}
u=\bar{U}+u^{\prime}=\langle U\rangle+u^{\prime} & \text { (Without CCV) } \\
u=\bar{U}+u^{\prime}=\langle U\rangle+u^{\prime}+u_{c} & \text { (With CCV) }
\end{array}
$$

流体計測に用いられる流れの平均法には，大きく分けて時間平均法と空間平均法の二つがある. 前者の時間平 均は，同一座標点でオイラー的に観測した流速時間履歴をローパスフィルタにかけることで，カットオフ周波数 以下の低周波成分を平均流と定義する方法である．後者の空間平均法は，1 枚のベクトルマップにおける流速の 空間配列を対象とし，任意サイズのフィルタ空を用いることで空内の空間配列データを用い平均化を行う。一般 的には移動平均フィルタやガウス関数で重み付けをしたガウシアンフィルタなどが用いられる（Reuss, 2000 and Müller et al., 2010). その他のアプローチとして，固有直交分解（Proper Orthogonal Decomposition, POD）を用い流 れ場の低次元成分を抽出する方法も報告されている（Druault et al., 2005）.

時間平均法は, 式(2)に基づき時間平均流 $\bar{U}$ のサイクル変動を時間的変動として求めることができ, 乱れの定義 も「ある定点における時間変動する瞬時流の標準偏差」であることから，同じ時間べースの物理量として捉える ことができる. しかしながら，時系列データを扱う必要があるため, TR-PIV（Time-resolved PIV）による高周波 サンプリングが必要不可欠である.

空間平均法は, 1 時刻の瞬時流ベクトルマップにおける空間配列データから空間平均流 $\widehat{U}$ を求める方法であ り, 乱れの定義も空間的な変動成分となる. 波数ベースでフィルタリングすることから渦スケールを直接閾值と して使用でき，渦の取り扱いが明確であると言える．また，空間平均法の場合 1 枚の瞬時流速ベクトルマップか らでも空間平均流を求めることができるため，主に低周波サンプリングの逐次 PIV 計測で用いられる.

このように, 時間平均法と空間平均法では得られる結果が本質的に変わってくる. そのためサイクル変動解析 を行う上で，どのような変動を解析したいかの用途によって平均法を分けて考える必要がある.

一方，数值計算の分野では直接数值計算（DNS : Direct Numerical Simulation）の他に，平均モデルとして，時間 (レイノルズ）平均モデルの RANS（Reynolds Averaged Navier-Stokes）と, 空間平均モデルの LES（Large Eddy Simulation）がある. 燃焼を伴う筒内流動のような複雑流れの数值シミュレーションでは, 計算コストの都合から DNS ではなく, 後者 $2 つ$ 平均モデルがよく用いられる.これらの平均モデルの考え方は, 前述した平均法と理 論的に同じであるため, PIV による実験結果と数值計算結果の比較を行う場合, RANS には時間平均流, LES に は空間平均流を比較対象にするのが正しく, 例えばRANS と空間平均の組み合わせは時空間の異なる平均結果を 比較することになるため注意が必要である.

以上より, PIV に用いられる時間平均と空間平均の二つの平均方法は, 平均特性の違いからサイクル変動解析 に使用した場合, 得られる変動成分が異なる. また, 数值計算と比較する場合も平均法の特性を理解した上で比 較対象とする計算法を選ばなければならない，そこで本研究では，フィルタ特性を一致させた時間平均法および 空間平均法により, 瞬時流から時間平均流 $\bar{U}$ および空間平均流 $\widehat{U}$ を求め, その平均流の流れパターンおよびス ペクトル特性を比較すると共に, サイクル変動成分 $u_{c}$ の比較を行った. また, 時系列データが得られず時間平均 を行うことができない逐次 PIV 計測の場合でも，カットオフ周波数ベースの空間平均流を抽出寸るための可変フ イルタサイズ空間平均法を新たに提案する. 
Hokimoto, Kuboyama, Kaneko, Moriyoshi, Haramiishi, Watanabe and Iida, Transactions of the JSME (in Japanese), Vol.85, No.871 (2019)

\section{2. 実験装置および実験方法}

\section{$2 \cdot 1$ 可視化単気筒エンジン}

表 1 に本実験で用いた可視化単気筒エンジンの諸元を示す. 本可視化エンジン（小山ガレージ製）は，ヘッド に量産四輪車 $2 \mathrm{~L}, 4$ 気筒エンジンヘッドのうち 1 気筒を使用しており，排気量は $500 \mathrm{~cm}^{3}$ である．ボア×ストロー クは $86 \times 86 \mathrm{~mm}$ で, ペントルーフ部およびシリンダライナに石英ガラスを用い, 筒内全域を可視化することが可 能である．また，延長ピストンとピストン冠面中央部に設けた石英ガラス空により，ボトムビューによる筒内の 可視化，および筒内への光源の照射が可能である.

\section{$2 \cdot 2$ 光学系}

図 1 に光学系の概略図を示す. PIV の光源には, 波長 $527 \mathrm{~nm}$, 最大発振周波数 $10 \mathrm{kHz} / \mathrm{pulse}$ の高周波ダブルパ ルス Nd:YLF レーザ（New wave research, Pegasus PIV）を用いた．発振されたビームは，532 nm 用ミラーにより反 射し, 凹, 凸レンズを用いビーム径を調整した後, シリンドリカルレンズによりシート光へと変換した. シート 光は延長ピストン下に設けたミラーにより反射させ，ヘッド面へ向けて照射した．トレーサ粒子には，粒径およ そ $2 \mu \mathrm{m} の \mathrm{SiO}_{2}$ 多孔質中空粒子（鈴木油脂工業，ゴッドボール B-6C）を用い，粒子を封入したタンク内に圧縮空 気を通過させることで気流に乗せ，スロットル上流域に供給した。 トレーサ粒子は，吸気行程中に吸入空気と共 にスロットルを介し吸気される。レーザ照射により得られる筒内の Mie 散乱光パターンは, エンジン正面に設置 したダイクロイックミラー（IRIDIAN, 495DPS, HR> $500 \mathrm{~nm}$ : 99\%, HT 400 - $500 \mathrm{~nm}$ : 96.3\%）により反射され，マ クロレンズ（Nikon, Ai AF Micro Nikkor 105 mm F2.8D）を装着した CMOS モノクロハイスピードカメラ（Photron, SA-X2）により撮影される．なお，本光学系では PIV と同時に PLIF（Planar,Laser Induced Fluorescence）計測を行 うために構成されておりダイクロイックミラーによる波長選択をしているが，本論文で述べる PIV だけの場合， 波長選択は不要である.

撮影した粒子画像は PIV 解析ソフトウェア（DANTEC, Dynamic studio 2015a）用いベクトルマップヘと処理し た. 本ソフトウェアではFFT 相関法による処理を行い，64 x 64 pix, 32 x 32 pix, 16 x 16 pix. と探査領域を 3 段階 に変化させながら 50\%オーバーラップにより相互相関を取った. また, エラーベクトルは $3 \times 3$ vectors のメディ アンフィルタを用い除去した，そのベクトルデータを基に，オープンソースの数值計算ソフトウェア（Scilab Enterprises, scilab 5.5.2）を用いた自作プログラムにより, アンサンブル平均, 時間平均, 空間平均などの処理を行 い, ポスト処理のベクトルマップ作成では, グラフ作成ソフトウェア（i-WORKS, Graph R plus ver.1.58）を用いた.

Table 1 Specifications of the optical engine.

\begin{tabular}{ll|c}
\hline \hline Displacement volume & {$\left[\mathrm{cm}^{3}\right]$} & 500 \\
\hline Stroke & {$[\mathrm{mm}]$} & 86 \\
\hline Bore & {$[\mathrm{mm}]$} & 86 \\
\hline Connecting rod length & {$[\mathrm{mm}]$} & 139 \\
\hline Compression ratio & {$[-]$} & 9.2 \\
\hline Number of valves & 4 \\
\hline Material of cylinder liner & Quartz glass \\
\hline
\end{tabular}

図 2 にPIV 計測範囲を示寸. 可視化エンジンのボア $86 \mathrm{~mm}$ に対し, 石英ガラス密は $\Phi 40 \mathrm{~mm}$ である. そのた め, 照射可能なレーザシートの最大範囲も幅 $40 \mathrm{~mm}$ である. 本計測では, 奥行き方向はボア中心とし幅 $40 \mathrm{~mm} の$ 範囲を対象とした. 後述する周波数解析および波数解析では, 図中に示寸黄色×印の定点および黄色矢印で示す直 線に空間分布する流速データを対象とした.

表 2 に PIV 計測条件を示す。レーザシート厚さは「シートを直交する粒子の $\Delta t$ 秒間に移動する距離はシート 厚さの $1 / 4$ 以下が好ましい」というクォータールールに基づき $1 \mathrm{~mm}$ とした（Keane and Adrian, 1991）. 計測クラ ンク角は吸気始めの 358 deg.ATDC（After Top Dead Center）から圧縮行程後半の 714 deg.ATDC とし，サンプリン グ周波数 $3 \mathrm{kHz}$ の $2 \mathrm{deg}$.間隔（@1000 rpm）で計測を行った。この際, トレーサ粒子の粒径およびかさ密度から 
Hokimoto, Kuboyama, Kaneko, Moriyoshi, Haramiishi, Watanabe and Iida, Transactions of the JSME (in Japanese), Vol.85, No.871 (2019)

算出した粒子の周波数応答性は 99.3\%@ $3 \mathrm{kHz}$ であり, トレーサ粒子の流れへの追従性は十分である（可視化情 報学会, 2013). 本可視化エンジンはクランクシャフトに取り付けたロータリーエンコーダ (OMRON, E6B2CWZ3E) からの角度信号を基準に, レーザ発振トリガを分周回路およびパルスジェネレータ (nf, WAVE FACTORY WF1946）から生成しているため，エンジン回転とレーザ発振の同期がなされている．また，PIVの微小二時刻撮 影間隔 $\Delta t$ は，吸気行程で $25 \mu \mathrm{s}$ ，圧縮行程では $50 \mu \mathrm{s}$ と BDC（Bottom Dead Center）で切り替えることで，筒内の 平均流速に対し， $\Delta t$ 秒間の最適粒子移動距離 5 10 pix.を担保した（可視化情報学会，2015）. 高速度カメラのフ レームレートおよびシャッタースピードは固定とし，ダブルパルスを独立して発振させるフレームストラドリン グ（フレームまたぎ）撮影を行った。 なお連続計測サイクル数は，高速度カメラの搭載メモリの都合上，45 サイ クルとした.

以上の条件で，機関回転数 $1000 \mathrm{rpm}$ 一定でスロットルを絞った低負荷モータリング条件における筒内流動の TR-PIV 計測を行った.

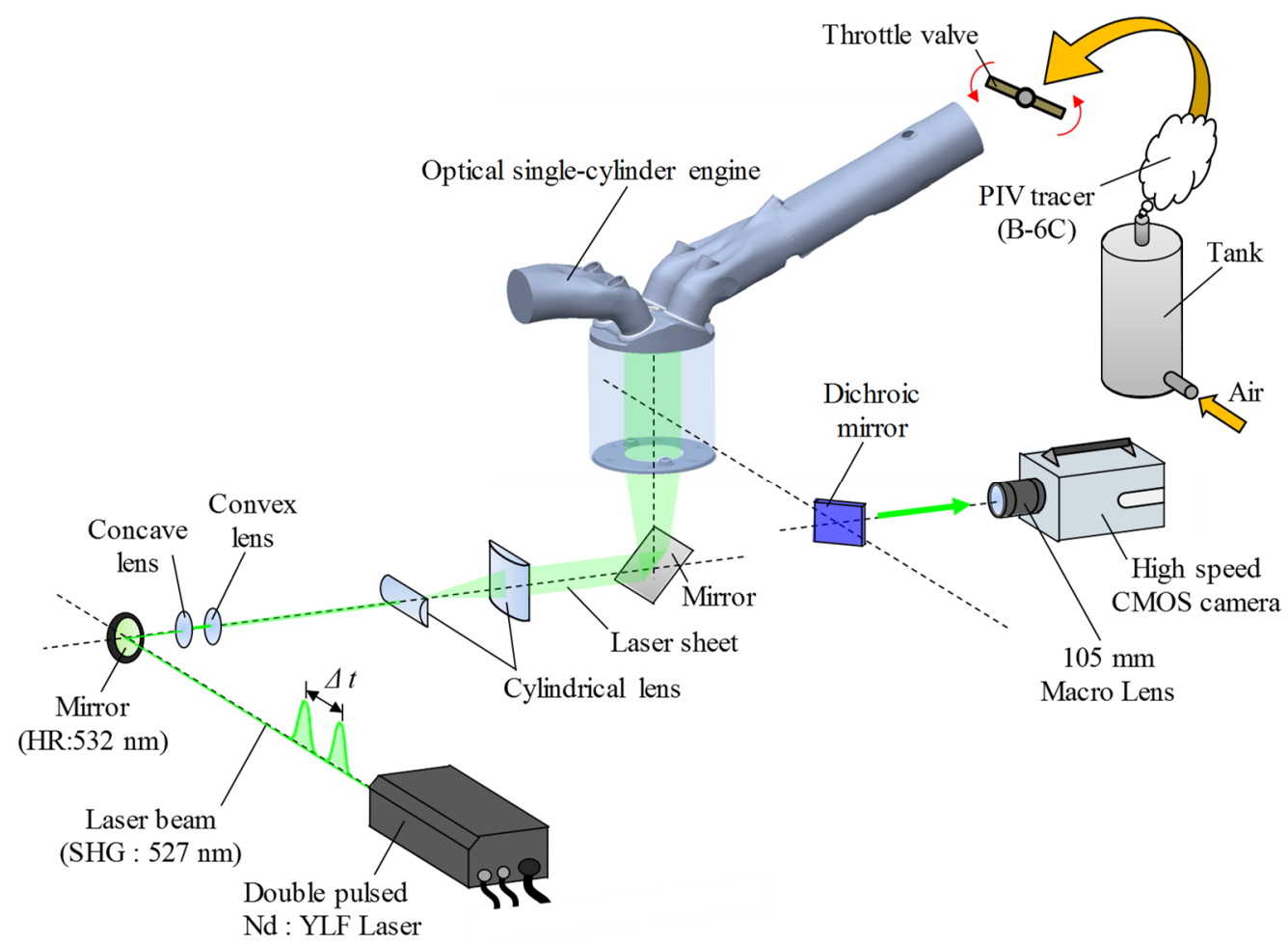

Fig.1 Schematic drawing of the optical setup.

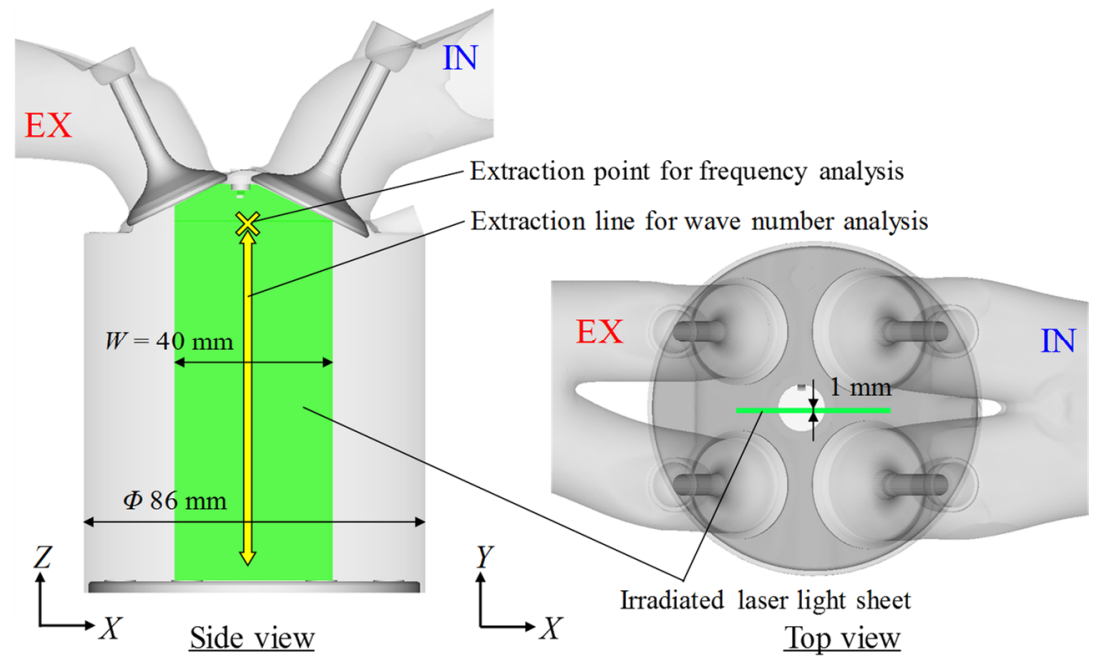

Fig.2 Measurement area of PIV. 
Hokimoto, Kuboyama, Kaneko, Moriyoshi, Haramiishi, Watanabe and Iida, Transactions of the JSME (in Japanese), Vol.85, No.871 (2019)

Table 2 Measurement conditions of PIV.

\begin{tabular}{ll|c}
\hline \hline Laser type & & Doubled Nd:YLF \\
\hline Wave length & {$[\mathrm{nm}]$} & $527(\mathrm{SHG})$ \\
\hline Sheet thickness & {$[\mathrm{mm}]$} & 1.0 \\
\hline Shot timings & {$[\mathrm{deg} . A T D C]$} & $358 \sim 714$ \\
\hline Time resolution in C.A. $\quad[\mathrm{deg}]$. & $2.0(3 \mathrm{kHz})$ \\
\hline $\begin{array}{l}\Delta t \text { between two laser shots } \\
\text { (for TR-PIV) }\end{array}$ & {$[\mu \mathrm{s}]$} & $\begin{array}{c}25 \text { @ Intake stroke } \\
50 \text { @ Comp. stroke }\end{array}$ \\
\hline Frame rate & {$[\mathrm{fps}]$} & 20000 \\
\hline Shutter speed & {$[1 / \mathrm{s}]$} & 20416 \\
\hline Spatial resolution & {$[\mathrm{pix}]$.} & $672 \times 1024$ \\
& {$[0.8 \mathrm{~mm} / \mathrm{vector})$} \\
\hline Measured cycles & {$[\mathrm{cycles}]$} & 45 \\
\hline
\end{tabular}

\section{3. 平均化手法}

\section{$3 \cdot 1$ ローパスフィルタリング}

カットオフ值よりも低い值を取り出す方法であるローパスフィルタリング（Low-pass filtering）は，大きく分け て二つの方法が用いられる. 一つは時系列または空間系列の流速データをフーリエ変換することで, 周波数また は波数パワースペクトルを求め, カットオフ周波数またはカットオフ波数以上のパワーが小さくなるような関数 を掛け，逆フーリエ変換で元の次元へと戻す方法である．フーリエ変換の実際として FFT（高速フーリエ変換） やDFT（離散フーリエ変換）がある．前者はデータ数が 2 の累乗個に制限されるのに対し後者にはその制限がな い. この方法の利点は処理の高速化が可能であることだが注意が必要で, フーリエ変換を行う際に, RAWデータ が周期的に連続する波形として処理を行うため，有限区間の RAW データにおいてデータ開始点とデータ終了点 の值が大きく異なる場合，周期間の繋ぎ目に“波形の段差”が生じ，そのスペクトルも結果に反映されてしまう. その対策として空関数を用いたウィンドウイング（Windowing）により，なるべくデータの端が近い值になるよ うに重みづけする方法がある。 これならばデータの繋ぎ目におけるエラーを減らすことが出来るが，データ点数 が少ない RAW データの場合，空関数を用いても周期的に連続するという仮定の影響で正しいスペクトルが得ら れない場合が多い.

もう一つの方法として，畳み込み積分を用いた方法がある。これは，フーリエ変換のように周期的に連続する 波形として扱うことなく直接フィルタリングできるため, データ点数が比較的少ない PIV 計測にも有効であると 考えられる. またフーリエ変換を用いないため RAW データと同じ次元のまま平均化を行えるため, フィルタの 特性が明確である．しかしながら，データ端へのフィルタリングはフーリエ変換と同様難しく課題がある.

本研究では時間平均および空間平均を同じフィルタリングにより処理し比較するため, ローパスフィルタリン グの手法は，時空間どちらも後者に挙げた空関数の畳み込み積分を用いた．図 3 にデータ端における畳み込み積 分の概略図を示す，時系列流速データでは，固定点でオイラー的に観測したデータであるため，ピストン移動に より観測点がピストンよりも下にある場合, 流動場ではないのでデータが存在しない. 本研究では, そのような データが存在しない領域にはゼロを代入して処理したため, 図 3 に示寸ようにデータの開始と終わりの流速はゼ ロとなる．黑線で示す RAW データに対し，赤線で示す空関数を右方向へと畳み込んでいく．図中の密関数は矩 形波であるが実際の処理ではガウス関数の空を用いた．図 3 (a)の場合，RAW データに対し空がおよそ半分重な る状態となっており, 本来はフィルタ空サイズが確保できないため平均化は行えない. しかし, 有限である RAW データを平均化する際に，空の大きさによっては平均出来るデータ点数が極端に減少してしまい，平均化できる データ自体がなくなってしまう場合がある. 本研究ではそれを回避する方法として, 図中黄色の丸で囲んだ空内 に存在する RAW データのみを使用して平均化を行った。つまりデータ端では本来のフィルタ空よりも小さな空 で平均処理を行い, データ端では厳密にはカットオフ值は増加している.ただし, 全域一定のカットオフ值でフ 
Hokimoto, Kuboyama, Kaneko, Moriyoshi, Haramiishi, Watanabe and Iida, Transactions of the JSME (in Japanese), Vol.85, No.871 (2019)

イルタリングする手法は他に存在しないため,この方法を使用した，空内が全てRAWデータとなれば，図 3 (b) に示すようにそのデータを用いガウシアン平均を行った.

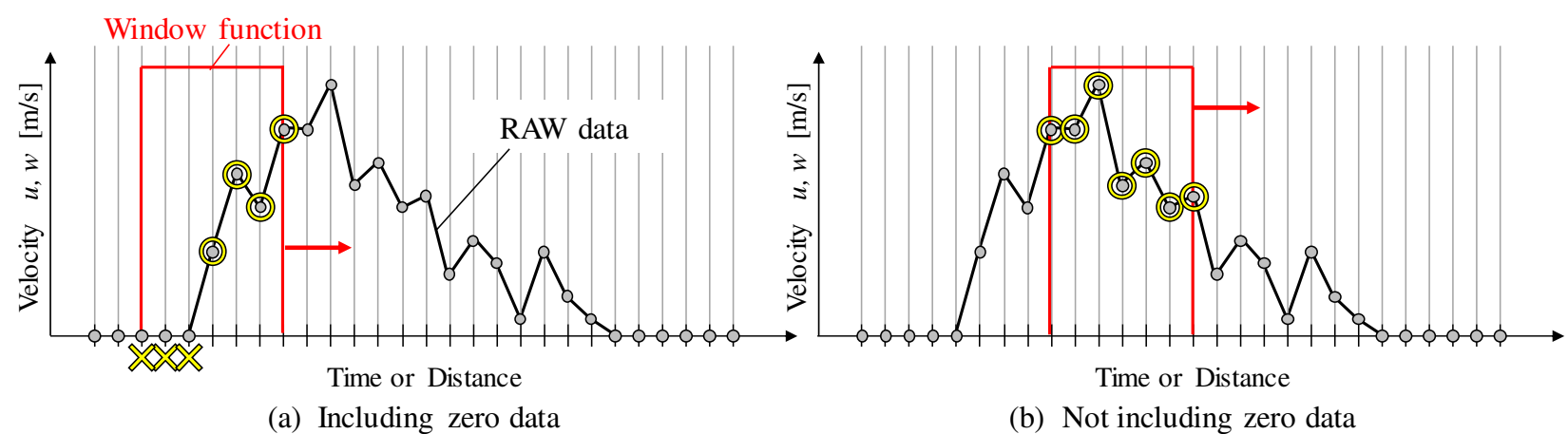

Fig.3 Strategy of convolution.

\section{$3 \cdot 2$ 窓関数}

本研究では，畳み込み積分に空関数としてガウス関数を用いた. 式(3)にガウス関数の式を示す. ガウス関数は 分母にある分散 $\sigma^{2}$ にって関数の急峻度合が左右され，その形状が変化する. そのため, フィルタ空サイズの他 に分散も重要なパラメータとなる，そこでまずは，分散を変えた際のフィルタ特性を比較する. 本研究では分散 $\sigma^{2}$ はフィルタ空サイズ $N$ に応じて変化させるために, 式(4)に示す式で定義した. ここで, 分母の $\alpha$ は分散の絶対 值を調整するための係数である.

$$
\begin{aligned}
& h_{g}(x)=\frac{1}{2 \pi \sigma^{2}} \exp \left(-\frac{x^{2}}{2 \sigma^{2}}\right) \\
& \sigma=\frac{(N-1)}{\alpha}
\end{aligned}
$$

図 4 に矩形波およびガウス関数の空関数とそのパワースペクトルの比較を示寸．ここでは時間配列データに対 する空関数について検討したが，空間配列データの場合も同様の考え方をすることができる. 図 4(a)に各空関数

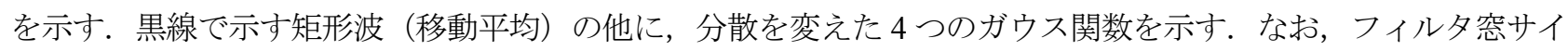
ズ $N$ は固定值とし，その幅よりもガウス関数が大きくなる場合は関数をカットし，值をゼロとした． $\alpha$ を変えて 分散を変化させると, 分散が小さくなる程ガウス関数が急峻になる. 図 4(b)に, 図 4(a)の関数をそれぞれフーリ エ変換したパワースペクトルを示す，黒線で示寸矩形波の場合，急峻なカットオフとなるが，サイドローブと呼 ばれる高周波域のスペクトルも確認できる。これが移動平均の欠点でありカットオフ值以上の高周波数または高 波数がフィルタを通過してしまう，ガウス関数の結果を見ると，分散が最も小さい青線の結果では，サイドロー ブは確認できないものの，メインローブに当たる部分のカットオフが緩慢となる. ガウス関数の分散を大きくす るにつれ，メインローブは細くなるが，それに加えサイドローブが発生する。これは図 4(a)より，ガウス関数が 緩慢になる程，フィルタ空サイズ $N$ 固定の制約から全体的な形状としては矩形波に近づくからである，そこで本 研究では，なるべくメインローブが細く，サイドローブの影響が少なく済むように橙色線で示す $\alpha=4$ を使用し た.

カットオフ周波数 $f_{c}$ はサンプリング周波数 $f_{s}$ および移動平均点数（フィルタ空サイズ） $N$ より，下式によって 定義される.これはフィルタ空の適用周波数を意味する.

$$
f_{c}=\frac{0.443}{N} \cdot f_{s}
$$

フィルタ空サイズ $N$ 移動平均において, パワースペクトルのゲインが $-3 \mathrm{~dB}$ になるときの周波数をカットオフ 周波数 $f_{c}$ と定義するのが一般的であり，その場合の係数として 0.443 が用いられる（小沢，1979）. 図 4 (b)の青 
Hokimoto, Kuboyama, Kaneko, Moriyoshi, Haramiishi, Watanabe and Iida,

Transactions of the JSME (in Japanese), Vol.85, No.871 (2019)

破線で示すのが $-3 \mathrm{~dB}$ ラインである.この式の関係は係数 0.443 によって成り立つものなので，ガウス関数を用 いた場合, 当然係数も変化する. そこで本研究で用いる $\alpha=4$ の分散によるガウス関数とカットオフ值の関係性 を次に調べた。

図 5 に矩形波のカットオフ值と同じ值になるようにフィルタ空サイズを調整したガウス関数を示す。黒線で示 す $N=13$ の矩形波はパワースペクトルのゲインが $-3 \mathrm{~dB}$ の時にカットオフ周波数は $100 \mathrm{~Hz}$ となる. 同様にガウ ス関数の場合は $N=19$ にすることで， $-3 \mathrm{~dB}$ 時のカットオフ周波数はほぼ同じ值をとり，なおかつサイドローブ の影響がほとんど無いことがわかる，この結果より，式(5)に用いる係数を計算すると，移動平均では 0.443 であ ったが, 本研究で用いるガウス関数の場合 0.612 となった. 以上より, 式(5)のカットオフ周波数とフィルタ空サ イズの関係式はガウス関数の場合, 下記の式(6)となる.

$$
f_{c}=\frac{0.612}{N} \cdot f_{s}
$$

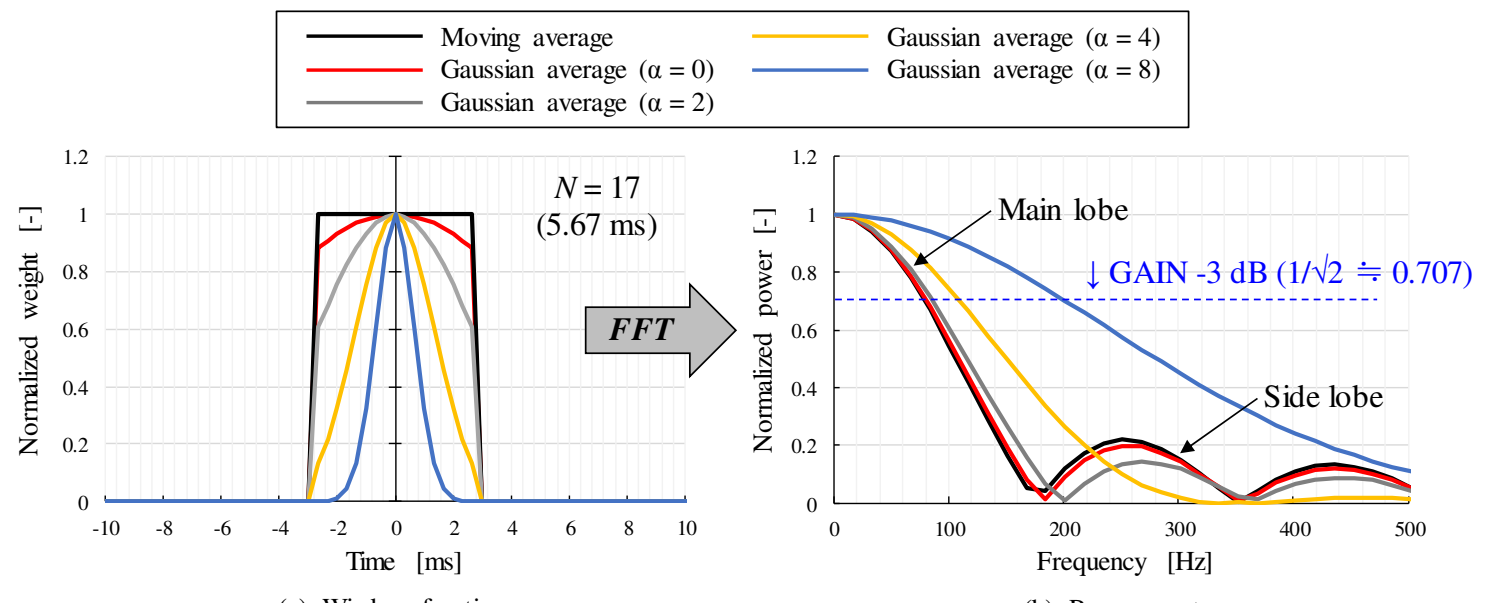

(a) Window functions

(b) Power spectra

Fig.4 Characteristics of the filter functions.

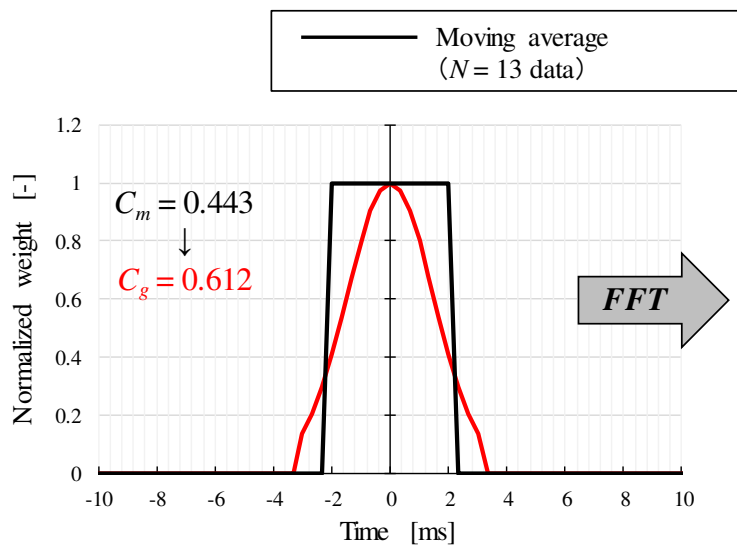

(a) Window functions
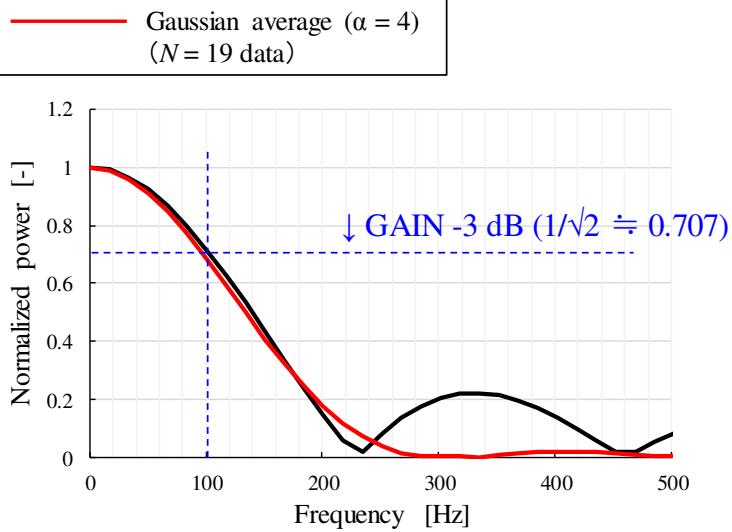

(b) Power spectra

Fig.5 Calculation of filter coefficient.

\section{$3 \cdot 3$ 時間平均法}

時間平均法では，TR-PIV から得られたベクトルマップより，同一座標における時間履歴の流速データを扱う。 図 6 に時間平均法のフローチャートを示す. 図 6 中央部にあるベクトルマップは，ある 1 サイクル中の瞬時流で あり, 画像奥から手前に向けてクランク角が進行する. 黄色×印で示す定点の流速時間履歴に着目すると, 黒線で 示すような流速時間履歴が得られる。この流速時間履歴を基に下記の手順により時間平均処理を行う. 
Hokimoto, Kuboyama, Kaneko, Moriyoshi, Haramiishi, Watanabe and Iida, Transactions of the JSME (in Japanese), Vol.85, No.871 (2019)

1. 流速（ $u, w$ 成分）が空間配列された 1 サイクル分のベクトルマップから，クランク角違いの同座標データ を抽出し，定点時間配列へデータを置き換える（流速時間履歴の抽出）.

2. 抽出された流速（ $u, w$ 成分）の時間履歴は，それぞれガウス関数を重みとした畳み込み積分を行う．その 結果，図中右下赤線で示すような時間平均流速履歴が得られる.

3. 赤線で示した時間平均流速履歴を，再度クランク角ごとに元の空間配列へと戻す.

4. 上記一連の処理をPIV で計測した全座標, 全サイクルで行う.

以上の処理により, 瞬時流ベクトルマップから時間平均ベクトルマップを作成した。ここで, 同一座標を時系 列に追跡すると，座標によってはピストン移動に伴い，流速データが存在しなくなる場合がある．その場合はゼ ロを代入し，全座標で同じデータ点数の時系列流速履歴とした．なお，ローパスフィルタに使用したカットオフ 周波数 $f_{c}$ の決定に関しては, 5 章 1 節で後述する.

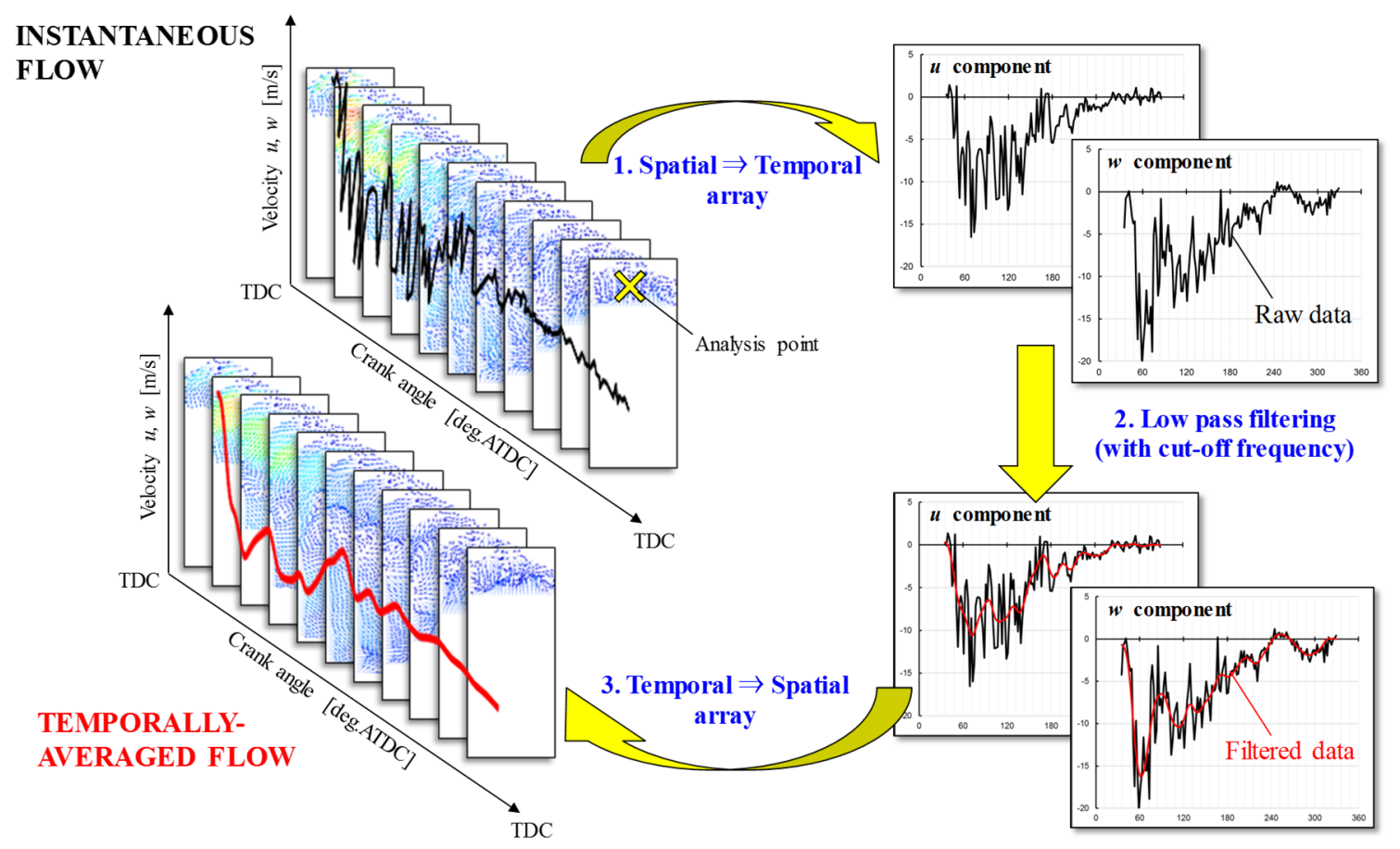

Fig.6 Flow chart of processing for the temporal-averaging.

\section{$3 \cdot 4$ 空間平均法}

時間平均法と空間平均法の結果を比較するため, 3.1 節および 3.2 節で述べた畳み込み積分とガウス関数による 重み付けは 1 次元の時間平均と 2 次元の空間平均で同じ方法を用いた. 図 7 に空間平均法の概略図を示寸ととも に下記の手順により空間平均処理を行う。

1. 平均化を行う座標とその周囲のフィルタ空サイズに該当する RAW データを抽出する. この時，フィルタ 空サイズは $N \mathrm{x} N$ 個の正方形とし， $N$ は奇数の整数とした.

2. フィルタ空サイズ $N \mathrm{x} N$ に合わせた 2 次元ガウス関数を式(3)および式(4)から算出し, 最大值で正規化した 重夕を先に抽出した $N \mathrm{x} N$ 個の RAW データにかける. なお，式(3)は 1 次元なので，これを 2 次元に展開 したものを使用する.

3. ガウシアン平均は図中に示寸式により計算を行う. 式中の添え字 $i$ および $k$ は $N \times N$ の密内における $X$ 座 標および $Z$ 座標であり, ガウシアン平均流速 $\widehat{U}$ は, 空内における重み付けをした RAW データの積算值を 空内におけるガウス関数の重みの積算值で除した值となる.この計算を流速 $u, w$ 成分それぞれで行う.

4. 得られた平均流速 $\widehat{U}$ を初めに抽出した座標（空中心座標）へ戻寸. この処理を PIV の計測全座標で行うこ とで，瞬時流ベクトルマップの空間平均を行う.

以上がガウシアン平均を用いた空間平均法の手順である.フィルタ空サイズには任意性があるため $N$ とたが, 具体的な $N$ の決定方法は後述していく. 


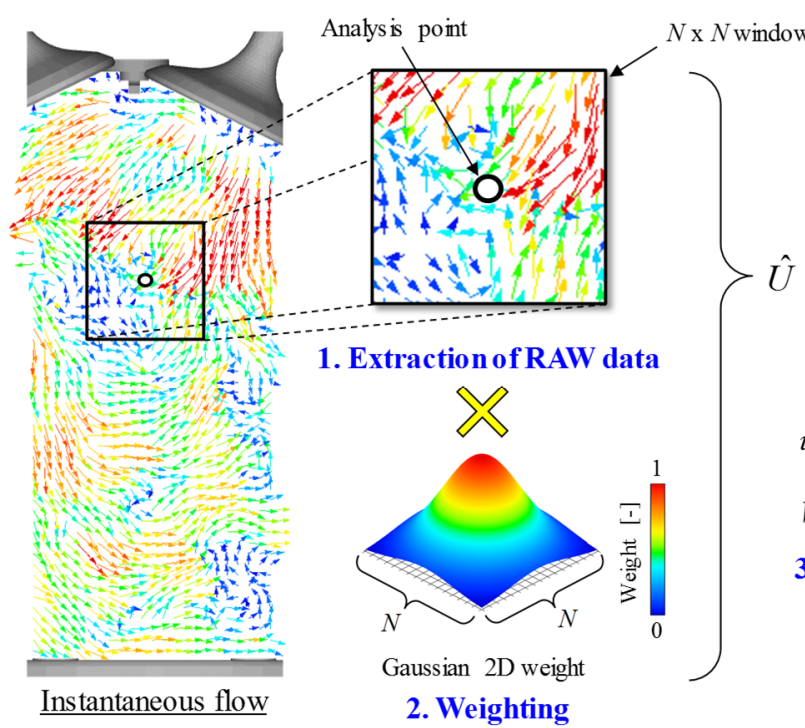

Fig.7 Flow chart of processing for the spatial-averaging.

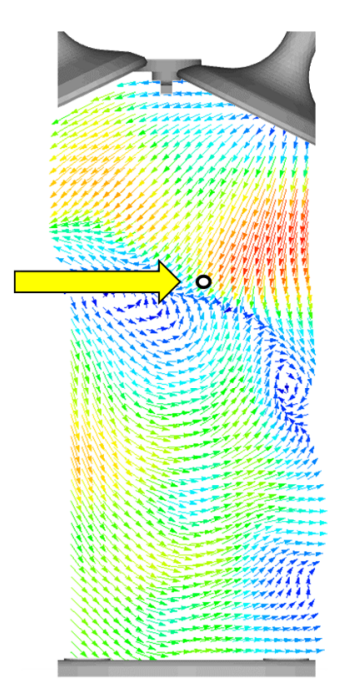

Spatially-averaged flow 4. Restoration to array

\section{$3 \cdot 5$ 可変サイズ空間平均法}

本研究では新たに，ある時刻におけるベクトルマップに対しフィルタ空サイズ空間的に変化させることで，複 数時刻のベクトルマップから処理する時間平均と同様のベクトルマップを空間平均法から求める方法を検討した. 可変フィルタ空サイズ空間平均法の概略図を図 8 に示寸. 図 $8(\mathrm{a})$ は一般的に用いられている空間平均で，対象範 囲全体のフィルタ空サイズが同一である. 本研究ではこの方法を以降, 固定サイズ空間平均法と呼ぶ. 固定サイ ズ空間平均法では，フィルタを適用する流速に関わらず同じ大きさの空，同じガウス関数を重みとして与え平均 を行うため, 空間的なカットオフ波数は同じでも, 時間的なカットオフ周波数は流速の違いから局所で変化する. そのため, カットオフ周波数を一定で空間フィルタリングするには, 図 8 (b)に示すように局所流速に応じて空間 フィルタ空サイズを変更する必要がある. 本研究ではこれを可変フィルタサイズ空間平均法と呼ぶ. なお，図で は各空の間に隙間があるが, 実際の処理ではデータ点ごとにフィルタ空サイズを決め, 全空間座標で処理を行う.

局所流速に応じたフィルタ空サイズ $N$ は以下の式により計算する. 式(7)左には式(6)にも挙げたように, ガウシ アン平均におけるカットオフ周波数 $f_{c}$, サンプリング周波数 $f_{s}$, そして平均点数 $N$ の関係式である. 周波数と 波数は次元が異なるだけで同じ振る舞いをすると考えると, 式(7)右のようにカットオフ波数 $k_{c}$ およびサンプリ ング波数 $k_{s}$ でも定義することができる. ここで，サンプリング波数 $k_{s}$ は PIV の空間分解能である. 式(8)左に示 すのはテイラーの乱流凍結仮説で, この仮説より周波数と波数の変換を行い, 式(8)右のように周波数と波数どち らもカットオフ值に直した，最終的に，式(7)右および式(8)右より，式(9)左が得られ，任意カットオフ周波数を用 いた局所流速に応じたフィルタ空サイズ $N$ を求めることができる. 3.3 節で述べた時間平均法では, 流速 $u, w$ 成 分にそれぞれ同じカットオフ周波数 $f_{c}$ によるフィルタリングを行った. そこで, 同じ周波数ベースで空間平均を 行うため, 式(9)右に示寸ように $u, w$ 成分で同じ $f_{c}$ 相当のそれぞれ異なる $N_{u}, N_{w}$ を求め, フィルタリングを行っ た. なお，算出した $N$ は実数となるため， $N$ から最も近い奇数の整数を実際のフィルタ空サイズとした.

$$
\begin{aligned}
& f_{c}=\frac{0.612}{N} \cdot f_{s} \rightarrow k_{c}=\frac{0.612}{N} \cdot k_{s} \\
& k=\frac{f}{U} \rightarrow k_{c}=\frac{f_{c}}{U} \\
& N=0.612 \cdot \frac{k_{s}}{f_{c}} \cdot U \rightarrow N_{u}=0.612 \cdot \frac{k_{s}}{f_{c}} \cdot|u|, \quad N_{w}=0.612 \cdot \frac{k_{s}}{f_{c}} \cdot|w|
\end{aligned}
$$




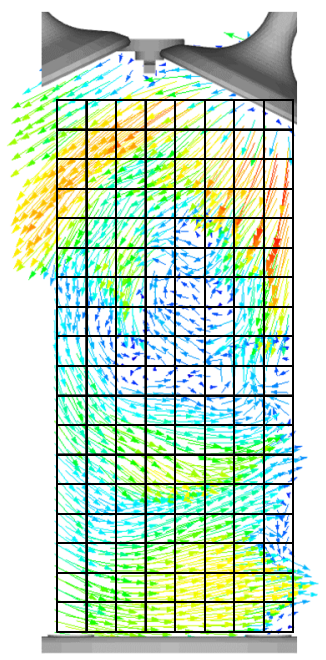

(a) Fix sized filter window (Conventional)

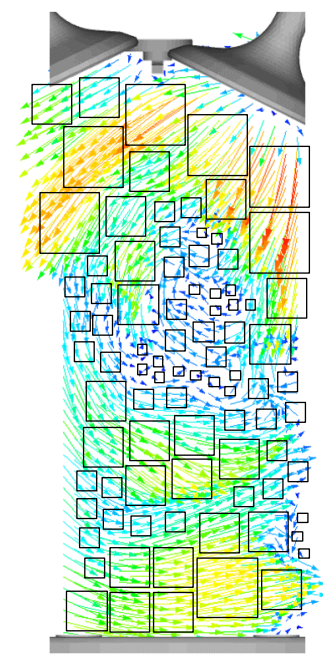

(b) Variable sized filter window

Fig.8 Schematic drawings of a variable sized spatial filter.

\section{4. 解析手法}

\section{$4 \cdot 1$ 乱れの相関法}

時間, 空間平均法のフィルタ特性を比較する上で, 筒内の平均積分長さスケールを用いた．積分長さスケール を求めるため, 任意 2 点間の相関関数を求める. まず変数の積の平均值は下式のように分解される.

$$
\begin{aligned}
\overline{u_{i} u_{j}} & =\overline{\left(\bar{U}_{i}+u_{i}^{\prime}\right)\left(\bar{U}_{j}+u_{j}^{\prime}\right)} \\
& =\bar{U}_{i} \bar{U}_{j}+\overline{u_{i}^{\prime} u_{j}^{\prime}}+\overline{\bar{U}}_{i} u_{j}^{\prime}+\overline{\bar{U}}_{j} u_{i}^{\prime} \\
& =\bar{U}_{i} \bar{U}_{j}+\overline{u_{i}^{\prime} u_{j}^{\prime}}
\end{aligned}
$$

$u$ は速度の瞬時値, $\bar{U}$ は平均值 (時間平均), そして $u^{\prime}$ は変動量（乱れ）を示しており, $\overline{u_{i}^{\prime} u_{j}^{\prime}} \neq 0$ の場合, $u_{i}^{\prime}$ と u相関があると言え, $\overline{u_{i}^{\prime} u_{j}^{\prime}}=0$ の場合, 相関がないと言える.ここで, $u_{i}^{\prime}$ および $u_{j}^{\prime}$ はそれぞれ時間の関数であ るため, 時系列変化する変動量（乱れ）の相関を求めなければならない，過去に Fraser らや大谷らは， 2 点同時 LDV を行うことで 2 点間の乱れ時間履歴の相関をとり積分長さスケールを算出し (Fraser and Bracco, 1988, 大谷 他，1990)，小保方らも光ファイバ LDVにより 2 点間の空間流速の相関を求めた (小保方他，1989). これら LDV の場合， 2 点同時計測しか行うことが出来ないが，高速 PIVを用いることで時間分解能は LDVに比べて劣るもの の，多点同時時系列計測が可能で多点同時相関を行うことが可能となる.

そこで本研究では，図 9 の概略図に示すような方法で乱れの相関関数を求めた. 図 9 左側に示すべクトルマッ プは，瞬時流から平均流を差し引いた乱れのベクトルマップである. 解析対象のクランク角を中心に示すべクト ルマップ (青枠) とすると, 乱れの時間履歴を得るために, 前後 2 時刻ずつのベクトルマップを参照した（計 5 時刻)。本研究の PIV 時間分解能は $2 \mathrm{deg}$.であるため, 合計クランク角にすると $10 \mathrm{deg}$. (1.66 ms @ $1000 \mathrm{rpm})$ と なる．その間は流体のスケールは変化しないと仮定し，水平直線状の空間配列データにおいての相関を求めるこ とにより, 図 9 赤線で示すような水平方向と時間方向の 2 次元検查領域における相関関数が得られる. この 2 次 元検査領域内で $\Delta x$ 離れた 2 点間の乱れの時間履歴は, 図中右側の実線と破線で示す関数として抽出することが でき，この関数の相関を求めることで積分長さスケールを算出する（式(11)). なお，図 9 に示した相関法は水平 相関となり， 2 次元検查領域を $t$ 軸周りに $90 \mathrm{deg}$. 回転させることで垂直方向の相関も求めた. 流速は $u, w の ~ 2$ 成 分を対象としたため，水平方向における縦／横相関と垂直方向における縦／横相関を得ることになる. 

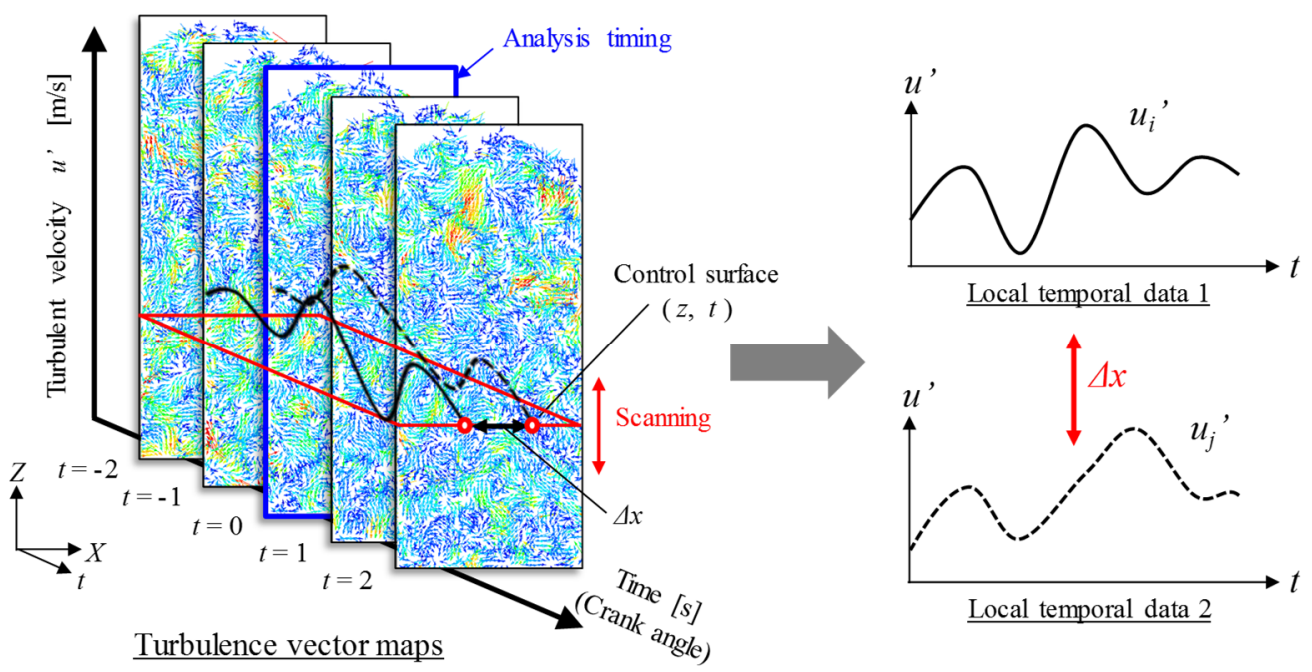

Local temporal data 1

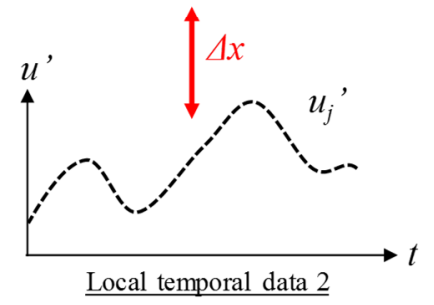

Fig.9 Cross-correlation of turbulence (Horizontal correlation).

$$
R_{\Delta x}=\frac{\sum u_{i(z, t)}^{\prime} \cdot u_{j(z, t)}^{\prime}}{\sqrt{\sum\left\{u_{i(z, t)}^{\prime}\right\}^{2} \cdot \sum\left\{u_{j(z, t)}^{\prime}\right\}^{2}}} \quad(j=i+\Delta x)
$$

\section{$4 \cdot 2$ 積分長さスケール $L$}

前節で述べた方法により得られた相関関数から積分長さスケール $L$ を算出する方法を図 10 に示す．流れの相 関では, 相関を行う方向に対し流速成分の方向が一致した場合を縦相関 ( $u$ 成分の水平相関 $/ w$ 成分の垂直相関), 相関を行う方向に対し流速成分の方向が $90 \mathrm{deg}$.回転した場合を横相関（ $w$ 成分の水平相関 $/ u$ 成分の垂直相関） と呼び，それぞれ相関関数の形状が変わる，縦相関の場合， $\Delta x$ が大きくなるにつれゼロに収束するが，横相関 の場合は $\Delta x$ が大きくなるにつれ一度負となりその後ゼロへと収束し, 一様等方性乱流の場合, それらから得ら れる積分長さスケール $L$ に 2 倍の差が生じる（日野，1992）。そこで本研究では, 縦/横相関それぞれで RAW データの近似方法を分けて考えた．図 10 に非線形最小二乗法による近似の概略図を示寸．図 10(a)に縦相関の場 合, 図 10(b)に横相関の場合を示す. 灰色線で示す RAW の相関関数は PIV 計測条件における分解能の問題であま り多くの統計量は得られておらず，データのばらつきが生じる．そこで縦相関の場合は青線で示すように指数関 数 $\exp$ の式で近似し, 横相関の場合は赤線で示すように $\exp * \cos$ の合成式で近似した. 近似したデータを基に, 閾值として $1 / e$ となる $\Delta x$ を積分長さスケール $L$ と定義した（浜本他，1992）.

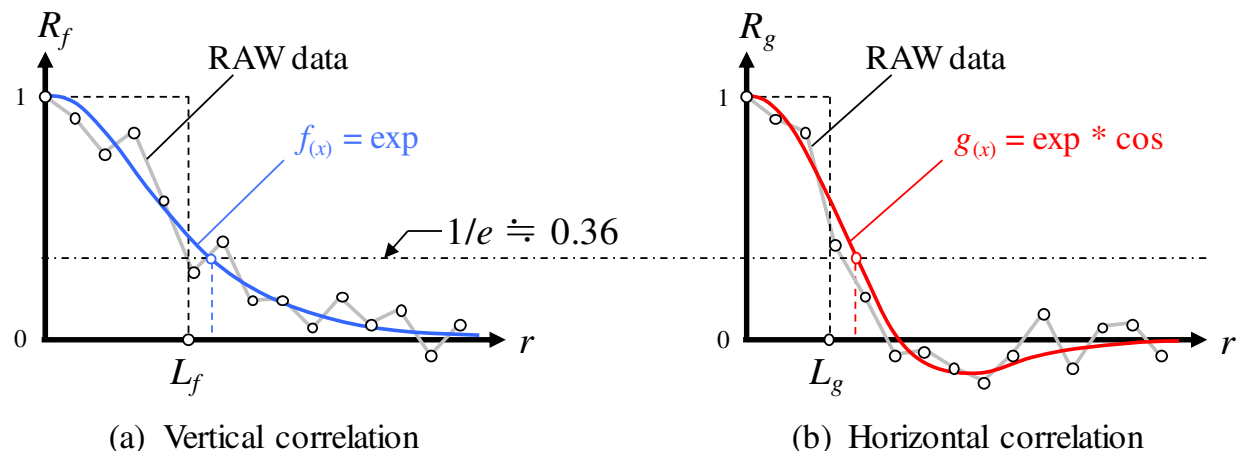

(a) Vertical correlation

(b) Horizontal correlation

Fig.10 Definition of length scale $L$.

ここで，検查領域内で任意距離 $\Delta x$ を変えた 2 点間の相関を取る際，有限区間内において $\Delta x$ が大きくなるほど 組み合わせ数が減少し, 相関を取るための統計数が低下していく問題がある. そのため, $\Delta x$ が大きく統計数の少 


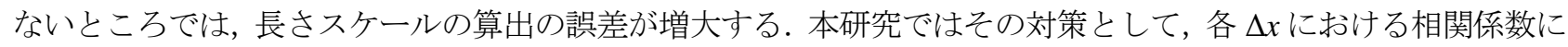
統計数の重みを与えた，重み付き非線形最小二乗法により $\exp$ の式および $\exp * \cos$ の式を近似させた. 式 (12)に 縦/横相関の近似式を示寸. 時定数 $B$ の初期值は適当な值を与え, $g_{(x)}$ を求める. 式 (13)により相関関数の RAW データ $h_{(x)}$ との誤差を求める. この時, 各距離 $\Delta x$ における統計数の重み $W t_{(x)}$ を掛け, この誤差が十分小さくなる まで時定数 B の収束計算を行った（式 (14)）（西原，1976）.

$$
\begin{aligned}
& f_{(x)}=\exp \left(-\frac{x}{B}\right), \quad g_{(x)}=\exp (-B \cdot x) \cdot \cos (B \cdot x) \\
& Q^{2}=\sum_{x=1}^{\max }\left\{h_{(x)}-f_{(x)}\right\}^{2} \cdot W t_{(x)}, \quad Q^{2}=\sum_{x=1}^{\max }\left\{h_{(x)}-g_{(x)}\right\}^{2} \cdot W t_{(x)} \\
& \frac{d Q^{2}}{d B} \approx 0
\end{aligned}
$$

\section{5. 実験結果および考察}

\section{$5 \cdot 1$ カットオフ周波数 $f_{c}$ の決定}

まず時間平均を行うにあたり，ローパスフィルタに使用する閾值，カットオフ周波数 $f_{c}$ を定義しなければなら ない．Iijima らは，LDV で計測した時系列流速履歴をフーリエ変換により処理することでアンサンブル平均流速 のパワースペクトルを求め, その最大周波数をカットオフ周波数と定義した (Iijima and Bracco, 1987). 神本らも, LDV により周波数スペクトルを求め, その周波数スペクトルの積分值が $90 \%$ に達した值をカットオフ周波数 $f_{c}$ と定義した (神本他, 1987). 大倉らは高速 PIV から得られた定点流速時間履歴の周波数スペクトルを求め, 周波 数スペクトルの傾きが変化する周波数において, 流動の変動特性が変化していると考え, その点をカットオフ周 波数 $f_{c}$ と定義した（大倉他，2013）。 また，Fansler らは平均流速の空間勾配からのカットオフ周波数決定を提案 した（Fansler and French, 1988）。これらの研究例を踏まえ，著者らも連続 45 サイクルの瞬時流とアンサンブル平 均流の周波数スペクトルを比較することで, アンサンブル平均のスペクトルに対し瞬時流のスペクトルが変動し 始める周波数をカットオフ周波数 $f_{c}$ と定義した（Hokimoto et al., 2017）. 本研究でも, モータリング低負荷条件で 計測した連続 45 サイクルを対象に，パワースペクトルと積分パワーを比較することで $f_{c}$ の検討を行った.

図 11 に定点データの流速強度履歴をフーリエ変換した周波数パワースペクトルを示す. 図 11 (a)は横軸に周波 数，縦軸にパワーを示す．図 11 (b)は縦軸に最大值で正規化した積分パワーを示す. 図 11 (a)より, 灰色線で示す 全 45 サイクルの同座標における瞬時流のパワースペクトルと赤線で示すアンサンブル平均の結果を比較すると, $100 \mathrm{~Hz}$ 以下の低周波数域では瞬時流とアンサンブル平均流は近いスペクトルとなるが，100 Hz 以上の高周波数域 では, 瞬時流のスペクトルは乱れの影響でパワーが高くなる. 本研究では, この $100 \mathrm{~Hz}$ を境に流体の特性が変化

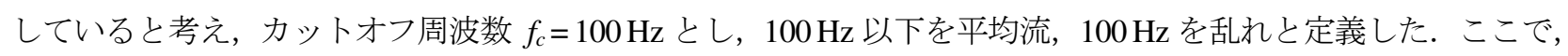
図 11(a)より大倉らの定義した周波数スペクトルの傾きが変化する点は, 丸プロットで示すように $120 \mathrm{~Hz}$ 付近に あり本研究の $f_{c}$ と近い值であった. また, 図 11 (b)より積分パワースペクトルでみると赤線で示すアンサンブル 平均の $100 \mathrm{~Hz}$ における積算值の割合は 78\%であり, 神本らの積分パワースペクトル 90\%よりも小さな值となり 差異がある.この理由として, 神本らは圧縮行程中の定点流速を基にした定義であるが, 本研究では吸気〜圧縮 端までの定点流速を基に定義したため, 流速のオーダが異なることから $f_{c}$ の定義に本質的な違いがあると考えて いる.

以上の結果より，本研究ではこの $100 \mathrm{~Hz}$ 付近を境目とし，低周波数域に平均流の成分が存在し，高周波数域に 乱れ成分が存在していると考え, カットオフ周波数 $f_{c}=100 \mathrm{~Hz}$ とし, $f_{c}$ はクランク角に依らず一定值を使用した. また，神本らも大倉らも $f_{c}$ は機関回転数依存であると述べており， $f_{c}$ の平均流速への依存性もあると考えられ， クランク角ごと, または空間ごとの平均流速に合わせた $f_{c}$ の変更が必要であるとも考えられる. しかしながら今 回の検討では，まずは時空間平均法の違いそのものを評価することを目的とし， $f_{c}$ は一定值を使用した. 


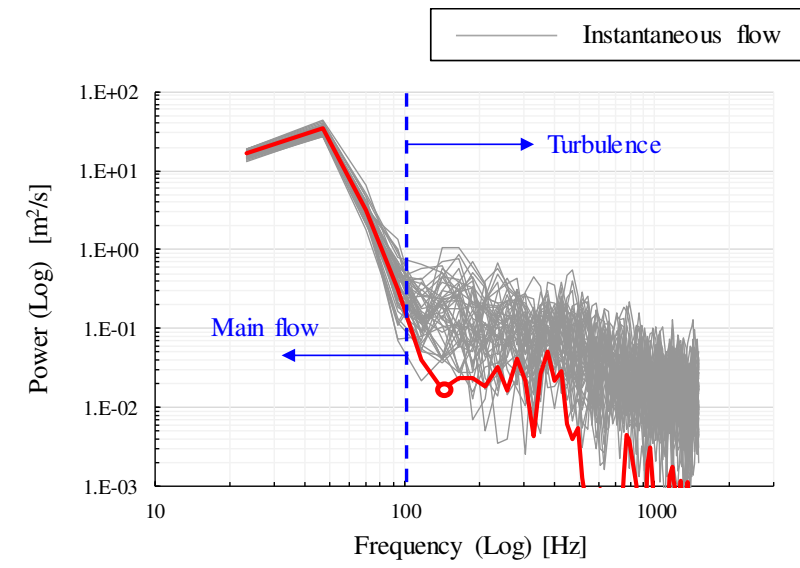

(a) Frequency spectra

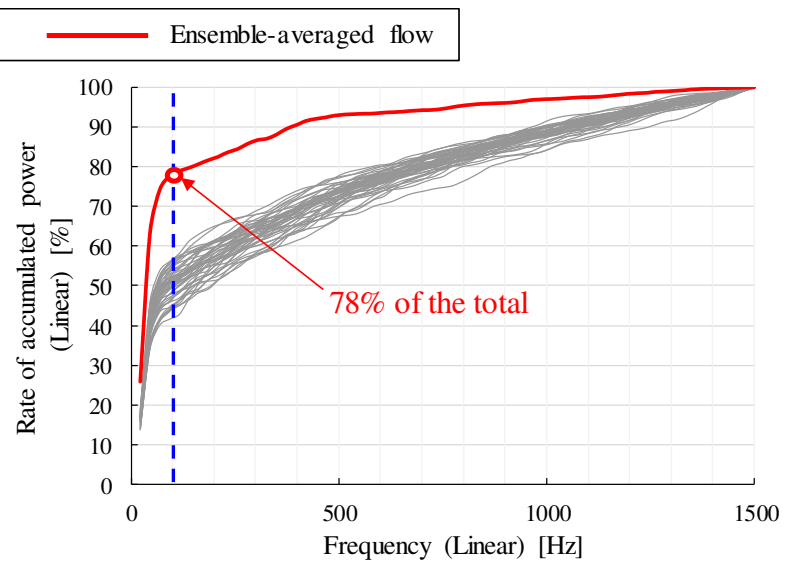

(b) Rate of accumulated spectrum

Fig.11 Results of flow analyses. Instantaneous velocities have high frequency components, compared to the ensembleaveraged velocity. As the slope of accumulated power changes at $100 \mathrm{~Hz}$, the cut-off frequency is defined at 100 $\mathrm{Hz}$.

\section{$5 \cdot 2$ カットオフ周波数 $f_{c}$ ベースのフィルタ言サイズ Nの決定}

カットオフ周波数 $f_{c}=100 \mathrm{~Hz}$ と定義したことで, 前章で示した各式より, 流速に対するフィルタ空サイズを 決定できる. 図 12 に式 (9)を用いて算出した流速強度とフィルタ密サイズの関係を示寸. 今回, 係数は 0.612 , サンプリング波数 $k_{s}$ はPIV の空間分解能から算出した $1156 \mathrm{~m}^{-1}$, そしてカットオフ周波数 $f_{c}$ は $100 \mathrm{~Hz}$ として計 算を行った. 本可視化エンジンの低負荷条件での吸気流速のオーダは最大で $25 \mathrm{~m} / \mathrm{s}$ 程度であるため, その時のフ イルタ空サイズはおよそ 177 x 177 data（152 x 152 mm） となり，PIVの計測範囲を大きく超えてしまう結果とな った. 本来ならば計測範囲を大きく超えるようなフィルタリングの結果に意味は無いが, 今回は可変フィルタサ イズ空間平均法の特性を確認するために 3.1 節で述べた畳み込み積分により, フィルタ内に存在するデータのみ を使用してガウシアン平均を行った.なお, 吸気行程中にはこのような要求フィルタ空サイズの問題が生じるが, 下死点以降の圧縮行程中では, 平均流速はおよそ $5 \mathrm{~m} / \mathrm{s}$ 以下になるため, 必要なフィルタ空サイズも 33 x 33 data 以下と小さくなり，相対的に妥当なサイズとなった.

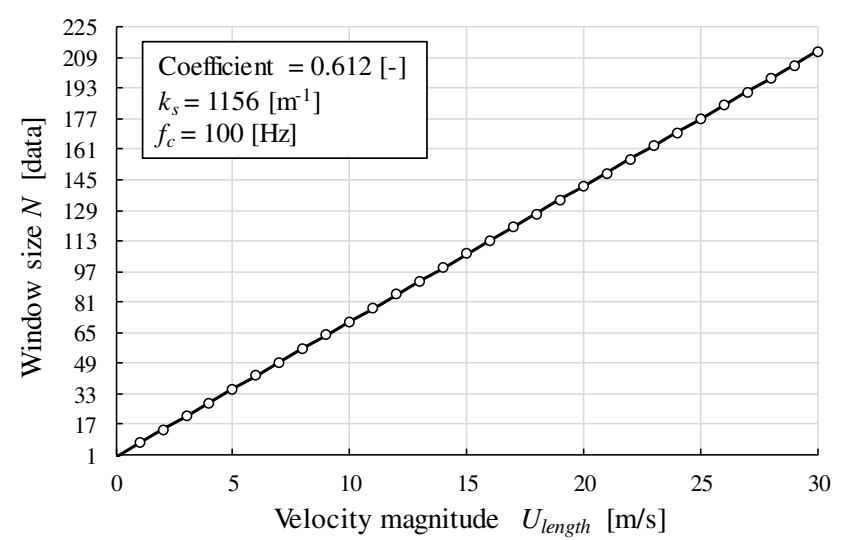

Fig.12 Relationship between velocity magnitude and window size. The plotted data were calculated using equation $9\left(f_{c}\right.$ $=100 \mathrm{~Hz}, k_{s}=1156 \mathrm{~m}^{-1}$, Coefficient $=0.612$ ).

\section{$5 \cdot 3$ 各平均法による積分長さスケール $\angle$ の比較}

図 13 に各平均法により得られた乱れ分布の相関をとることで算出した積分長さスケール $L$ の履歴を示寸.こ こでは, 図 13 (a)に $u$ 成分の縦相関により得られた長さスケール $L_{f u}$, 図 $13(\mathrm{~b})$ に $w$ 成分の縦相関により得られた 長さスケール $L_{f w}$ を示す. 同様に各成分を横相関することで得られた長さスケール $L_{g u}$ および $L_{g w}$ を図 13(c), 図 13(d)に示寸. 各プロットは, 青。に時間平均, 赤 $\Delta$ に固定サイズ空間平均, 緑×に可変サイズ空間平均の結果を示 
Hokimoto, Kuboyama, Kaneko, Moriyoshi, Haramiishi, Watanabe and Iida, Transactions of the JSME (in Japanese), Vol.85, No.871 (2019)

す.また，各プロットはクランク角ごとに図 9 に示した検査領域を計測範囲全体に移動させて取得した筒内全体 の空間平均値，かつ全 45 サイクルにおけるアンサンブル平均值を示した.

図 13 (a) 13 (d)までそれぞれの $L$ の傾向は異なるが，図 13 (a)の縦相関に着目すると時間平均の結果では, 吸 気行程から吸気終わり下死点にかけて $L$ は低下し, 圧縮行程中で暫く一定となった後, 圧縮行程後半で再度増加, TDC へ向けて減少する傾向となった。一般的に筒内流動における $L$ の傾向として, TDC 前にタンブルの崩壊に より乱れが生成されるため $L$ は少し増加し, 圧縮によってTDCで極小となることが知られている. 図 13(a) に示 寸結果では，時間平均結果では TDC（CA = $720 \mathrm{deg} . \mathrm{ATDC})$ に向けて極小に向かうが，固定サイズ空間平均の結 果では, むしろ増加傾向となった．また，可変サイズ空間平均の結果では，吸気行程中の傾向は時間平均の結果 とほぼ一致するが, 圧縮端前における $L$ の増加は他の平均法に比べ小さく, TDC までに僅かに減少するものの, 時間平均法とは差異がある. 図 13(b)および図 13(c)における結果では, 時間平均法と固定サイズ法は TDCへ向け てほぼ一定となり, 図(d)の結果では両者共に減少した。つまり 4 つの相関方向によって TDC で極小となる $L$ の 傾向が得られる場合とそうでない場合があった. 寸なわち, 図 13(a)の結果は時間平均法では一般的な $L$ の傾向が 得られているが，固定サイズ法では得られなかった。一方，図 13(b) (d)における可変サイズ法の結果では, TDC に向けた $L$ の減少が得られた. また全ての結果より, 吸気〜圧縮行程にかけた全体的な $L$ の傾向は, 可変サイズ 法は固定サイズ法に比べれば時間平均法に近い傾向を得た。

ここで, 一様等方性乱流の場合, 縦相関から得られた長さスケール $L_{f}$ は横相関から得られた長さスケール $L_{g}$ の 2 倍になる. 図 13 の結果では, 図 13(a) と図 13(c), 図13(b) と図 13(d)がその関係性に該当する. しかしながら, 本計測結果からは 2 倍となる結果は得られなかった. その理由として, 筒内流動は圧縮端では局所等方性乱流が 形成されていると考えられるが，全域一様等方性乱流とはならない. 図 13 に示した結果では PIV の計測範囲全 体の空間平均值をとったため, 局所等方性の結果と非等方性の結果が相殺し，2 倍の結果にはならなかったもの と考えられる.

図 14 に固定サイズ空間平均のフィルタ空サイズを変えた場合による $L_{f u}$ の結果を示す. 固定サイズ法の特性と して，フィルタ空サイズ $N$ を小さくすれば（カットオフ波数 $k_{c}$ を大きくすれば） $L$ の絶対值も小さい方へとシフ トした。 つまり図 13 に示した固定サイズ法の結果は, 図 14 で時間平均法とオーダがほぼ一致した 19x 19 data の フィルタ空サイズの結果を用いた。すなわち時間平均ありきのフィルタ空サイズの選定を行った結果である.

高速 PIV ならば時系列流速履歷が得られるため, このような固定サイズ法のフィルタ空サイズの選定が可能で あるが，逐次 PIV ではフィルタ空サイズの選定を行うことは出来ず適当なサイズを用いる他にない，そこで可変 フィルタサイズ法を用いることで，1 枚のベクトルマップからでも $L$ の傾向を時間平均の結果に近づけることが できる．ただし前節でも述べたように，可変サイズ空間平均法では吸気行程中のフィルタ空サイズは場所により PIV の計測範囲を超える大きさとなるため, 平均法を適用する流速範囲に注意する必要がある.

\section{$5 \cdot 4$ 各平均法による平均流ベクトルマップの比較}

図 15 に，ある 1 サイクルにおける瞬時流および各平均流のベクトルマップをそれぞれ示す．図 15 (a)に RAW データである瞬時流, 図 15 (b)にカットオフ周波数 $100 \mathrm{~Hz}$ で時間平均した時間平均流, 図 15 (c)にフィルタ空サ イズ 19 x 19 で空間平均した固定サイズ空間平均流, そして図 15 (d)にカットオフ周波数 $100 \mathrm{~Hz}$ ベースで空間平 均を行った可変サイズ空間平均流を示寸. 図の結果はクランク角 CA で $390 \sim 690 \mathrm{deg}$.ATDC まで $50 \mathrm{deg}$. 間隔で示 した．なお，流速は吸気／圧縮行程で大きく異なることから， ベクトルのカラースケールは吸気行程中は $0 \sim 25$ $\mathrm{m} / \mathrm{s}$, 下死点以降は $0 \sim 6 \mathrm{~m} / \mathrm{s}$ とした.

吸気行程前半の CA = 440 deg.ATDC までの結果では，PIV 計測範囲のほとんどが吸気ポートからの流れパター ンとなる，各平均法の結果を見ると，時間平均流および固定サイズ空間平均流は近い流速のオーダとなるが，可 変サイズ空間平均流では明らかに流速が低くなった。 これは前述した通り, 要求されたフィルタ空サイズに十分 なデータ量が確保できなかったため, 高流速域では正しいフィルタリングが出来ていないことが原因である. CA $=490$ deg.ATDC では, 計測範囲中心付近にタンブル渦中心が形成されているが，固定サイズ空間平均流を見ると 時間平均流に比べ, 明らかに乱れが除去 (平滑化) されていることがわかる. 一方, 可変サイズ空間平均流では, タンブル渦中心付近のベクトルパターンは時間平均流に近い結果となり, 流速が遅い領域でフィルタ空サイズが 縮小し，高波数成分が通過していることがわかる．下死点以降のベクトルマップを比較してみても，明らかに時 
Hokimoto, Kuboyama, Kaneko, Moriyoshi, Haramiishi, Watanabe and Iida, Transactions of the JSME (in Japanese), Vol.85, No.871 (2019)

間平均流と可変サイズ空間平均流は，絶対值に対象の差異はあるものの流れパターンはほぼ一致しており，相対 的に固定サイズ空間平均流は過剰な平均化がされていることがわかる.

ここで，時間平均流と可変サイズ空間平均流の流速の絶対值に差が生じてしまった原因として，フィルタリン グを行う次元の違いが影響していると考えられる. 時間平均流では，時間方向の流速履歴をフィルタリングし， 可変サイズ空間平均流では一定カットオフ周波数相当のフィルタリングを行うものの，対象とするデータは空間 方向の流速配列である. そのため平均化の特性は時間平均と可変サイズ空間平均で同じであっても，そもそも平 均化する対象データがデータ中心点以外は全て異なる. その結果, 絶対值までは完全に一致させることは出来ず, 時間平均法と空間平均法を近づけるための限界はそこにある.

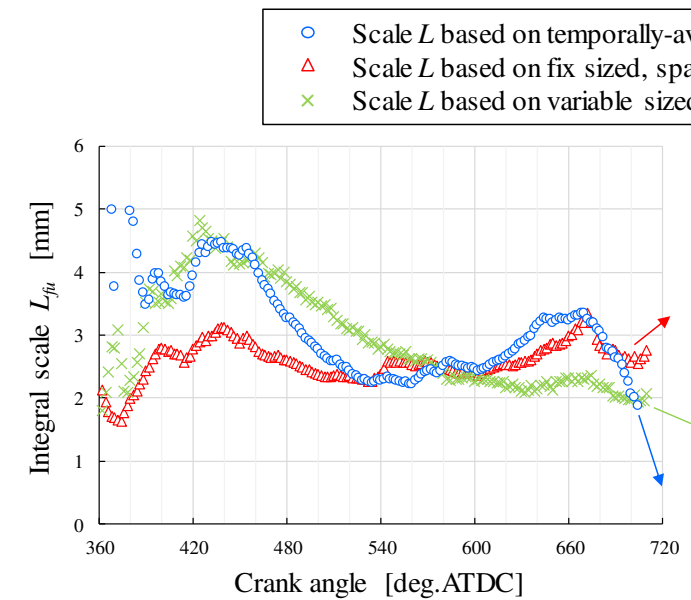

(a) Vertical correlation ( $u$ component)

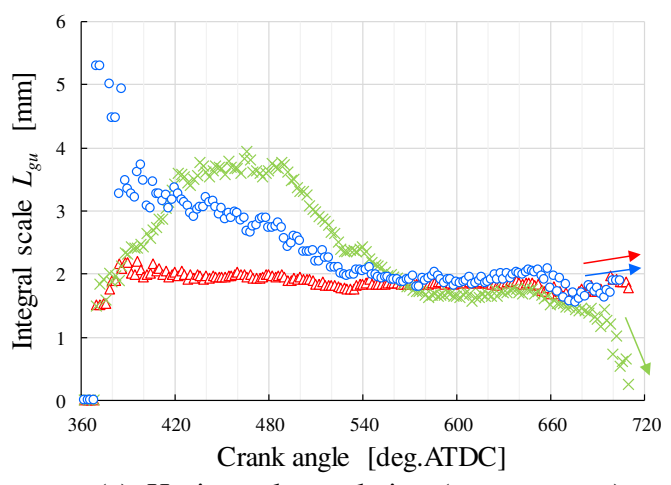

(c) Horizontal correlation ( $u$ component)
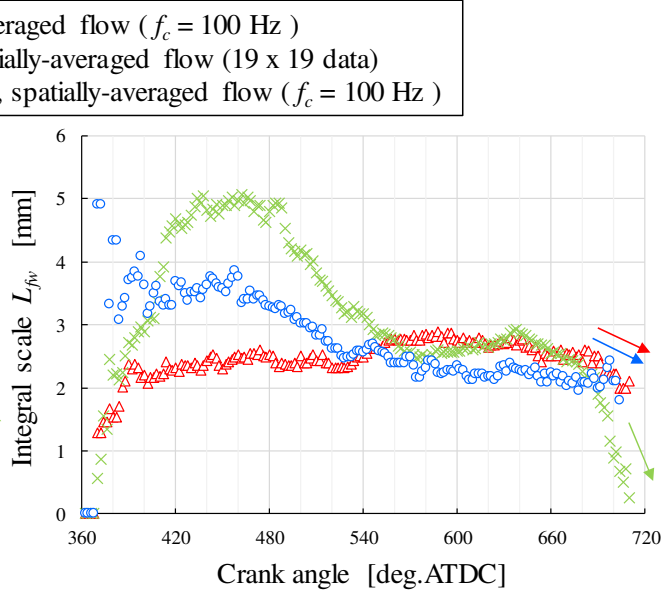

(b) Vertical correlation ( $w$ component)

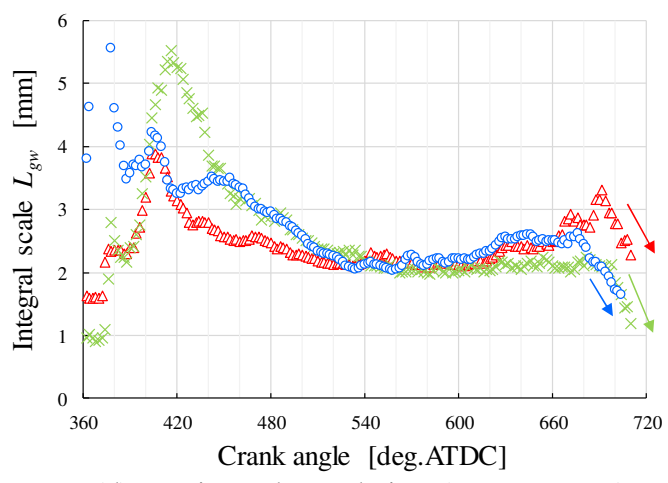

(d) Horizontal correlation ( $w$ component)

Fig.13 Comparison of three averaging methods on integral length scale $L$. Temporally-averaged flow's $L$ is approximately identical to variable sized, spatially-averaged flow's $L$ as a trend. Fix sized, spatially-averaged flow's $L$ only coincides during the compression stroke, compared with other averaging method.

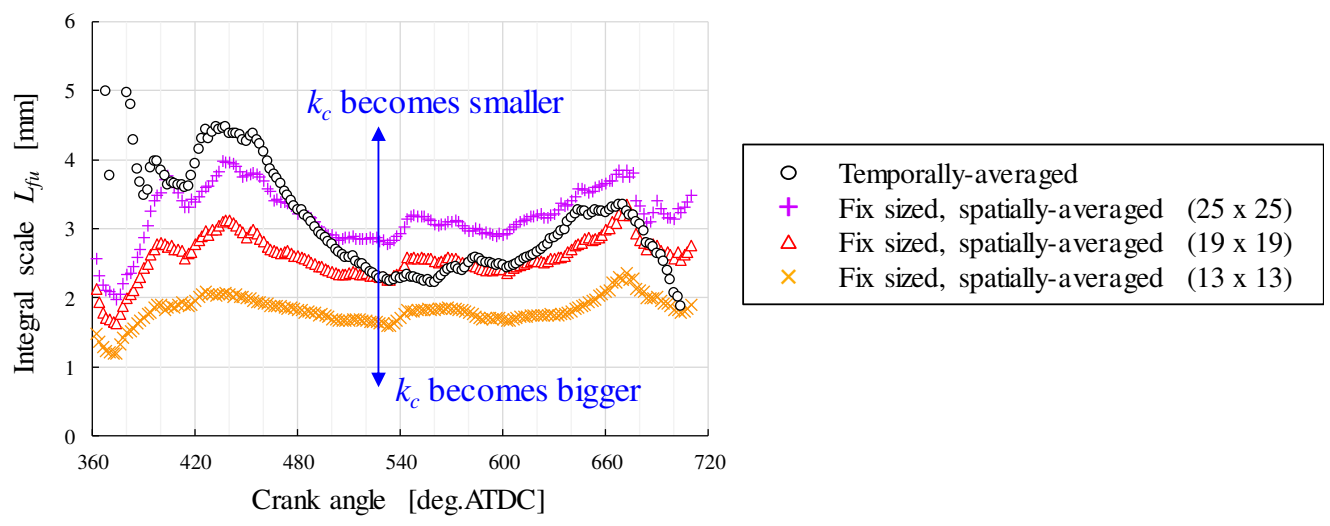

Fig.14 Comparison of filter sizes on integral length scale $L_{f u}$ in fix sized, spatial-filtering. Integral length scale decreases when filter size becomes small. Therefore, it is necessary to choose the filter size in fix sized, spatial-filtering. 
Hokimoto, Kuboyama, Kaneko, Moriyoshi, Haramiishi, Watanabe and Iida, Transactions of the JSME (in Japanese), Vol.85, No.871 (2019)
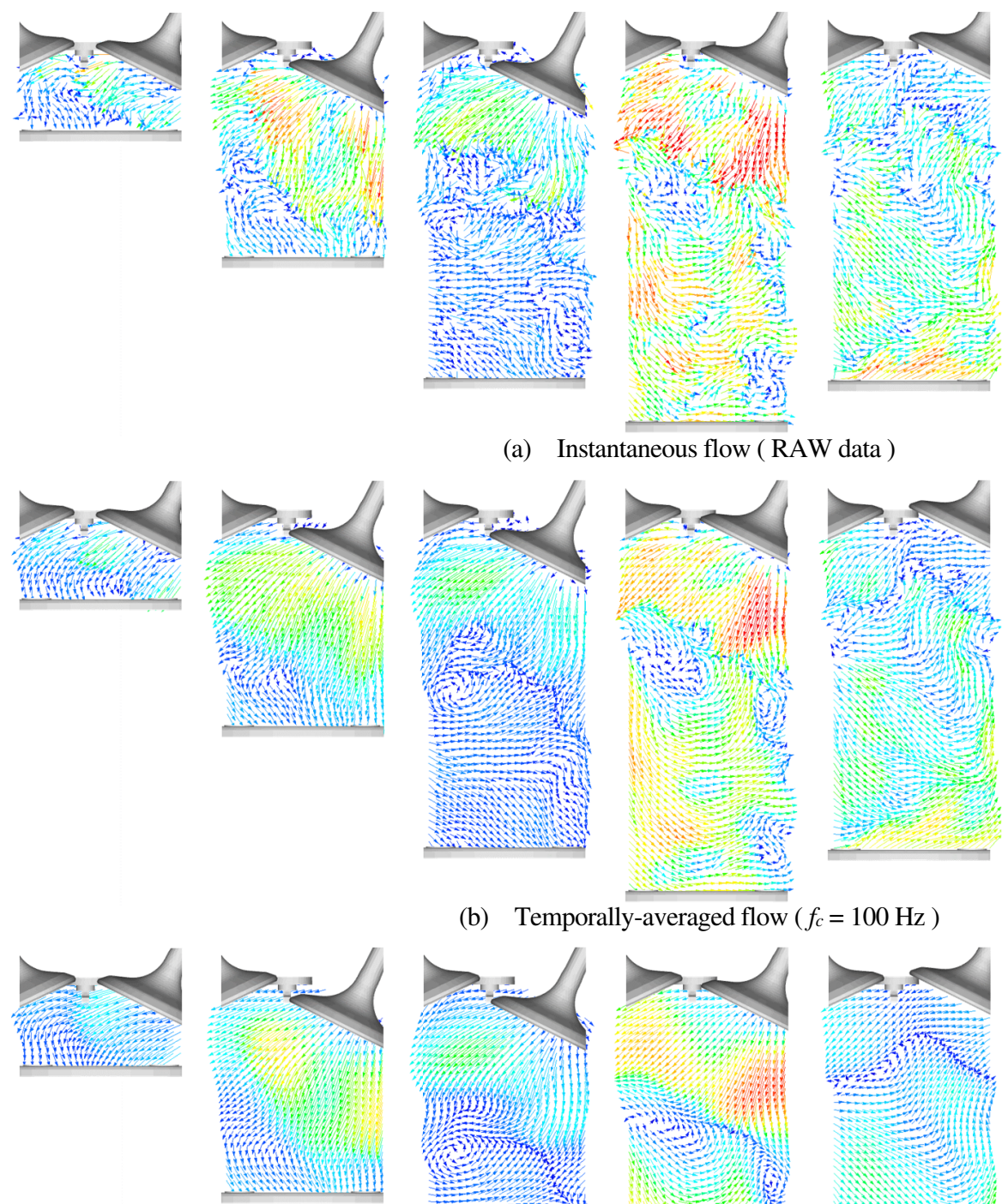

(a) Instantaneous flow ( RAW data )
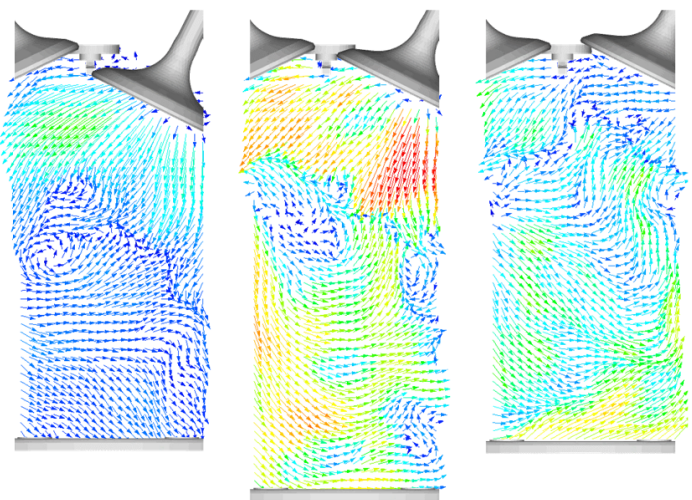

(b) Temporally-averaged flow $\left(f_{c}=100 \mathrm{~Hz}\right)$
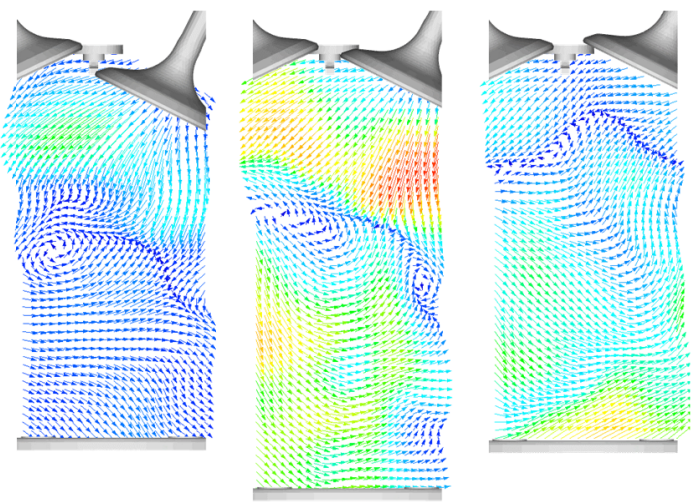

(c) Fix sized, spatially-averaged flow ( 19 x 19 data $\fallingdotseq 16.4$ x $16.4 \mathrm{~mm}$ )
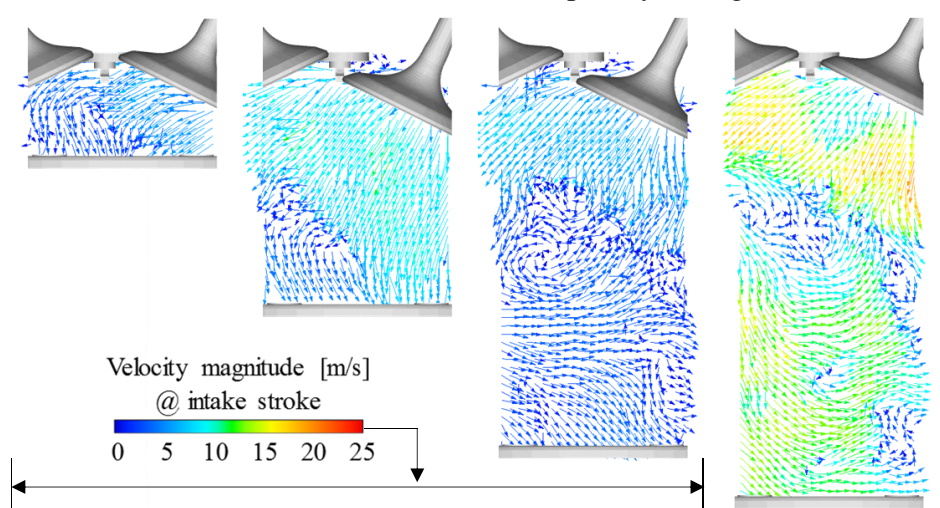

390 deg.ATDC

440 deg.ATDC

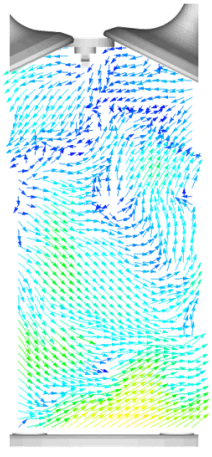

590 deg.ATDC
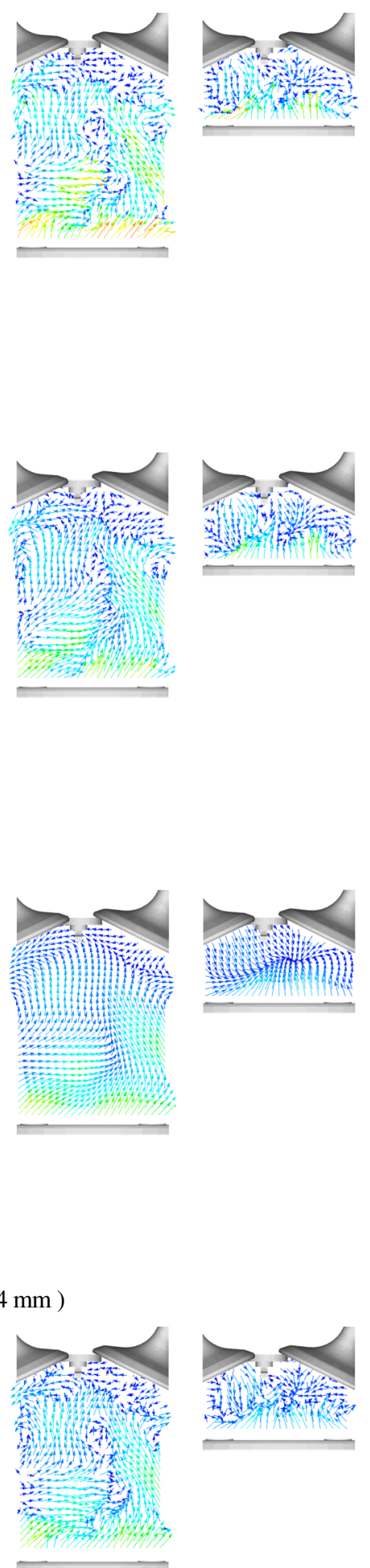

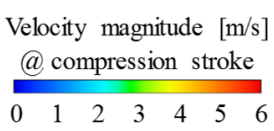

640 deg.ATDC
690 deg.ATDC

(d) Variable sized, spatially-averaged flow $\left(f_{c}=100 \mathrm{~Hz}\right)$

Fig.15 Comparison of vector maps that were indicated instantaneous flow (RAW data) and various averaged flow. Large flow structure is averaged by the large size filter and small turbulence passes through the small size filter with variable sized, spatially-averaging. As a result, vector map of averaged velocity in variable sized method is close to that in temporal-averaging method. 
Hokimoto, Kuboyama, Kaneko, Moriyoshi, Haramiishi, Watanabe and Iida, Transactions of the JSME (in Japanese), Vol.85, No.871 (2019)

\section{$5 \cdot 5$ 周波数 /波数パワースペクトルの比較}

前節では，平均流ベクトルマップより各平均法を比較し，時間平均と可変サイズ空間平均はベクトルマップの 見た目はほぼ一致した。 そこで次にスペクトル解析により各平均法の定量的比較を行った.

各平均法を周波数および波数パワースペクトルから比較した結果を図 16 に示す. 図 16 (a)に図 2 に示した×印 の定点で抽出した時系列の流速強度履歴をフーリエ変換した周波数パワースペクトル (ナイキスト周波数 $=1500$ $\mathrm{Hz}$ ) を示し，図 16 (b)に図 2 に示した下死点における同一線上の空間系列の流速強度履歴をフーリエ変換した波 数パワースペクトル (ナイキスト波数 $=578 \mathrm{~m}^{-1}$ ) を示す. 図中に示す黒破線は傾き-5/3 の直線で，黒実線で示す 瞬時流の高波数成分のパワースペクトルの傾きと比較するとほぼ一致することから，慣性小領域内のパワースペ クトルの傾きを再現出来ており，本計測結果の妥当性が確認できる.

図 16(a)より, 周波数スペクトルで見ると, 青線で示す時間平均流は黒線で示す瞬時流のスペクトルに比べ，カ ットオフ周波数に相当する $100 \mathrm{~Hz}$ からパワーが低下しており，時間平均が正しく機能していることがわかる. 一 方, $f_{c}=100 \mathrm{~Hz}$ 相当の空間平均を行った緑線で示す可変サイズ空間平均流では，時間平均に比べ高周波成分はほ とんど除去出来ていないことがわかる．赤線で示す固定サイズ空間平均流でも同様のスペクトルが得られ，二つ の空間平均は周波数スペクトルではほぼ同じ結果が得られた.

次に図 16 (b)より，波数スペクトルで比較すると，青線の時間平均流と緑線の可変サイズ空間平均流は，黒線 の瞬時流に比べ，同程度の波数フィルタ特性となっていることがわかる. 一方，図 13 より積分長さスケール $L$ が 時間平均結果と一致するように，フィルタ空サイズを調整した固定サイズ空間平均流（赤線）は，明らかに高波 数域のスペクトルが低下したことから，時間平均に比べ過剰な平均化がされていることがわかる.

以上の結果より，周波数ベースで空間平均を行う可変サイズ空間平均法は，従来の固定サイズ空間平均法に比 ベ，波数スペクトルを時間平均流のスペクトルに近づける効果があるものの，平均化に使用する次元が時間方向 ではないことから周波数スペクトルは一致せず，あくまで 1 時刻の流速空間配列上において時間平均流の流れパ ターンに近づけられることがわかった.

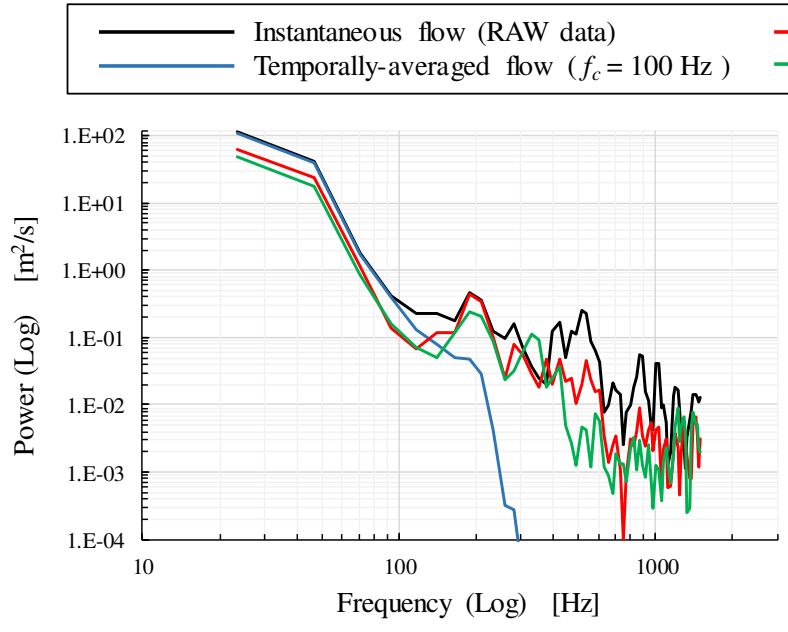

(a) Frequency spectra

\section{— Fix sized, spatially-averaged flow (19 x 19) Variable sized, spatially-averaged flow $\left(f_{c}=100 \mathrm{~Hz}\right.$ base $)$}

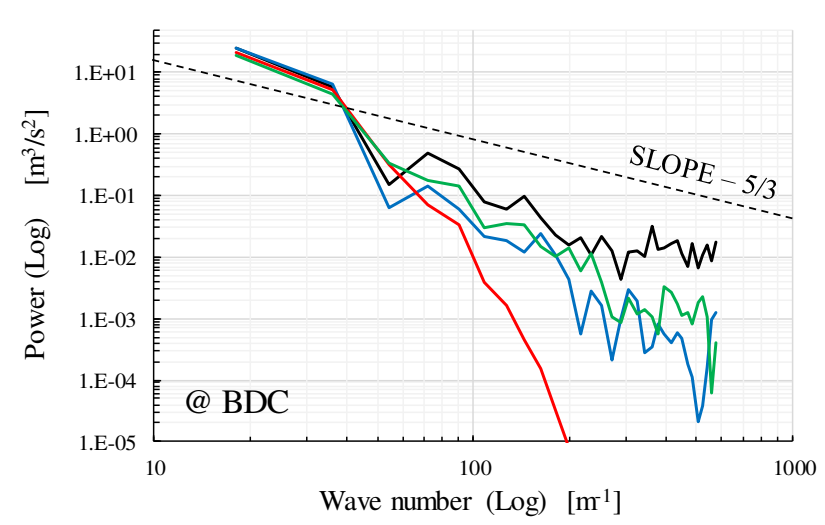

(b) Wave number spectra

Fig.16 Comparison of three averaging methods on frequency power spectrum and wave number power spectrum. Wave number spectrum in the case of variable sized, spatial-averaging is close to that of temporal-averaging. The filtering effect to high wave number region of fix sized, spatial-averaging is too strong.

\section{$5 \cdot 6$ サイクル変動流速の比較}

緒言でも述べたように，筒内流動のサイクル変動を評価する上で，時間平均と空間平均の二つの手法が用いら れている. そこでサイクル変動成分のベクトルマップを各平均法から求め, 比較を行った.

図 17 に各平均法から算出した 1 サイクル中のサイクル変動流速のベクトルマップを示す. ここで，サイクル 変動流速は，式(2)に示した「各平均流一アンサンブル平均流」より求めた. なお，アンサンブル平均流は連続 45 サイクルのサイクル平均結果とした. 
Hokimoto, Kuboyama, Kaneko, Moriyoshi, Haramiishi, Watanabe and Iida, Transactions of the JSME (in Japanese), Vol.85, No.871 (2019)

図 17 の各平均法の結果を比較すると, $\mathrm{CA}=440 \mathrm{deg}$.ATDC の吸気行程中では, 図 17 (a)の時間平均ベースと図 17 (b)の固定サイズ空間平均ベースの場合, 吸気バルブから少し離れた下流域に下向きの高流速成分が分布する流 れパターンとなるが, 図 17 (c)の可変サイズ法では, 吸気バルブ直下に吸気流れとは逆向きのベクトルが確認で きる.これは前述してきたように, 図 15 (d)に示した可変サイズ空間平均流の吸気行程は, 要求フィルタ空サイ ズの問題で正しいフィルタリングが出来ないため, 平均された流速が大きく低下してしまったことが原因である. その結果, 可変サイズに比べむしろ固定サイズの結果の方が定性的に時間平均ベースのサイクル変動パターンに 近づいた. 図 15 に示した平均流の場合と同様で, 下死点以降では可変サイズ法の要求フィルタ密サイズの問題は ほとんどないため, サイクル変動流速のパターンも時間平均から求めた結果とほぼ一致し，固定サイズ空間平均 法から求めた結果は, 圧縮行程中の細かい渦構造や流れの境界面も平滑化され過ぎてしまう結果となった.
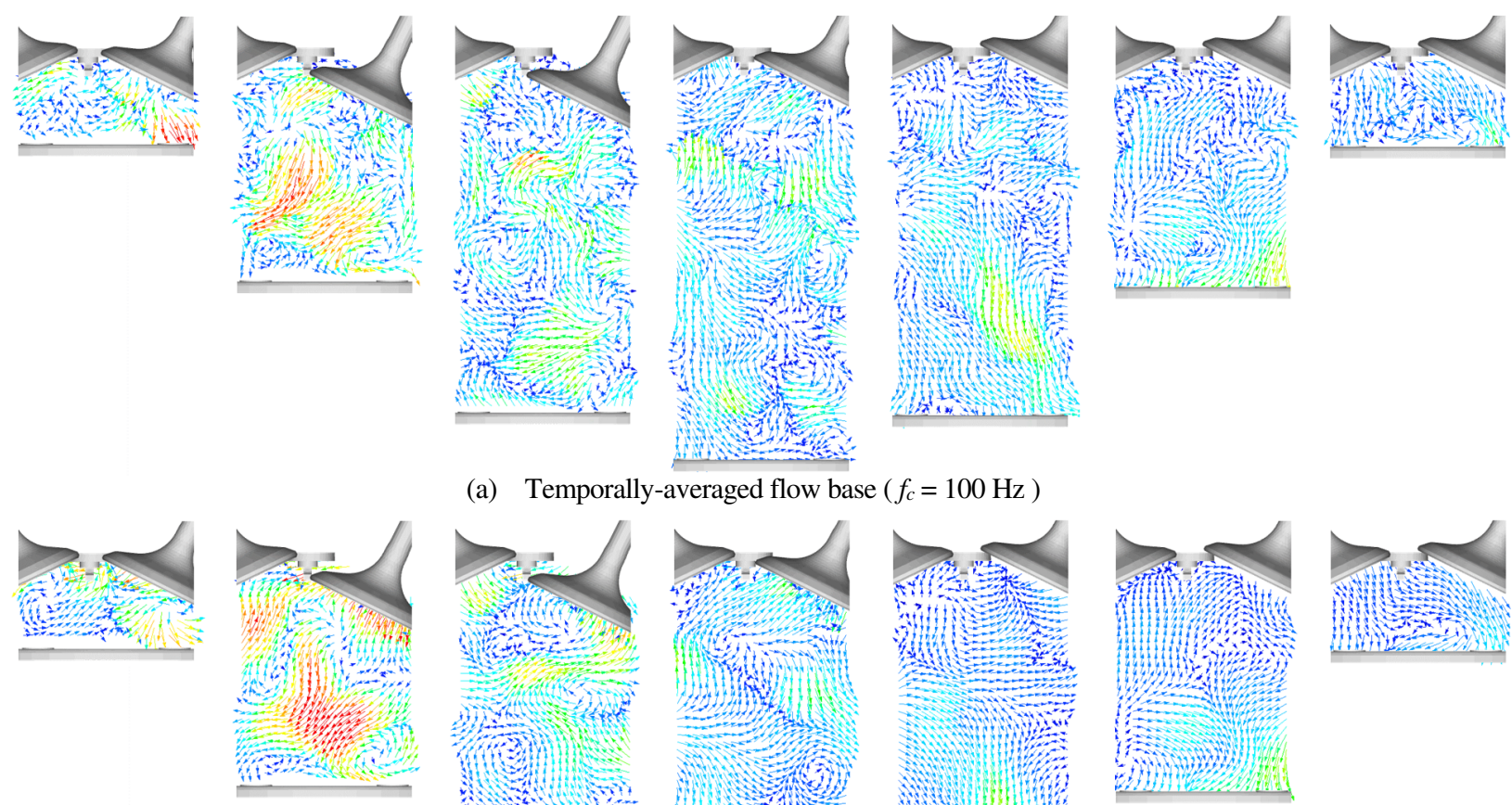

(a) Temporally-averaged flow base $\left(f_{c}=100 \mathrm{~Hz}\right)$
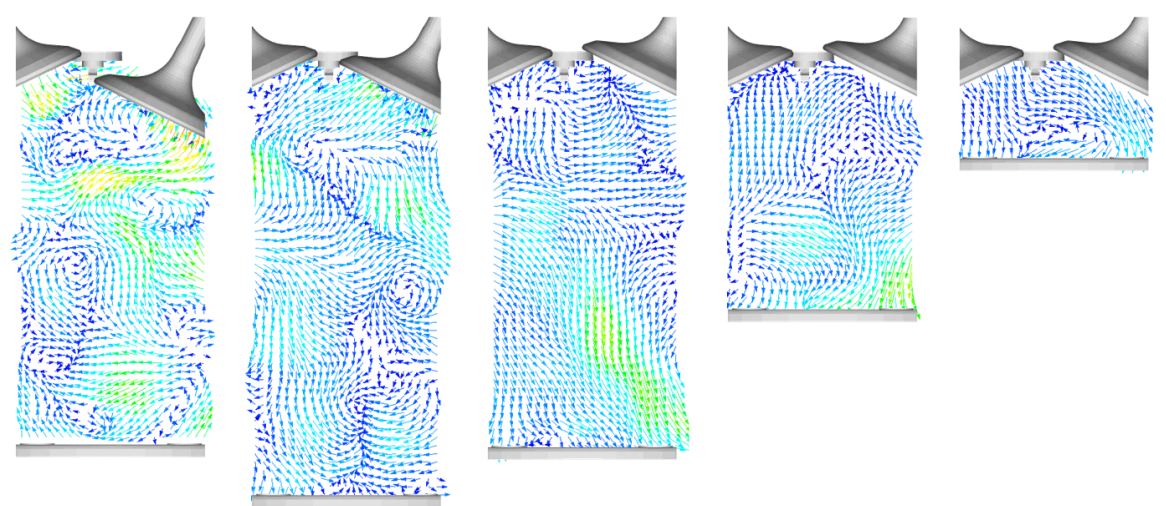

(b) Fix sized, spatially-averaged flow base ( 19 x 19 data $\fallingdotseq 16.4$ x $16.4 \mathrm{~mm}$ )

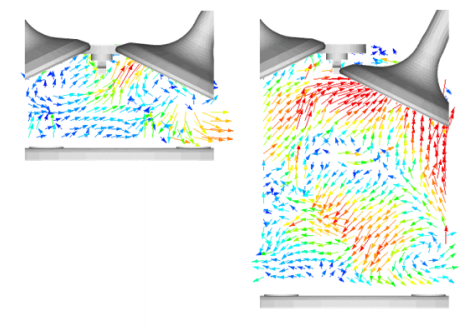

390 deg.ATDC

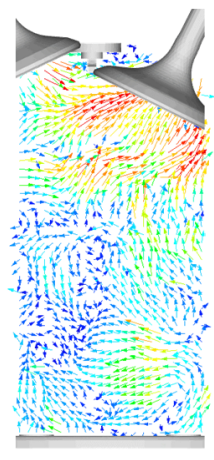

490 deg.ATDC

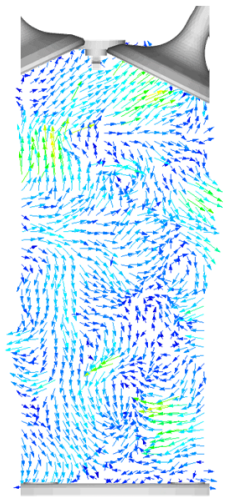

$\mathrm{BDC}$
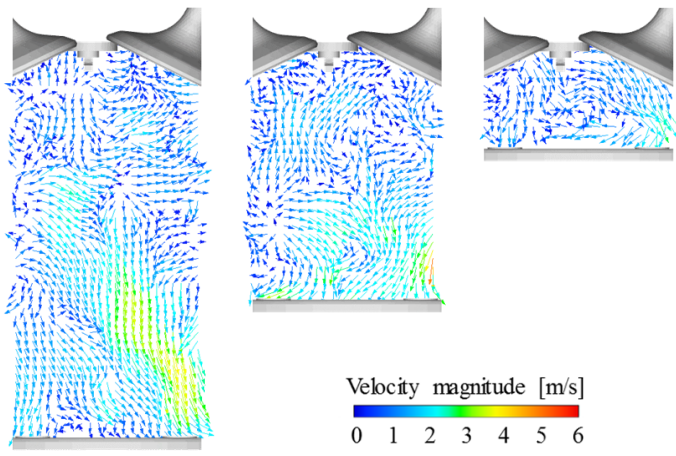

Velocity magnitude $[\mathrm{m} / \mathrm{s}]$

590 deg.ATDC $640 \mathrm{deg}$. ATDC $\quad 690$ deg.ATDC

(c) Variable sized, spatially-averaged flow base $\left(f_{c}=100 \mathrm{~Hz}\right)$

Fig.17 Comparison of vector map of CCV component. CCV flow pattern in the variable sized filter is close to pattern in the temporal-averaging, compared with the fix sized spatial filter as with averaged flow pattern (shown in Fig.15). However, the fix sized filtering method is close to the temporally-averaged during the intake stroke, compared with variable size method. 
Hokimoto, Kuboyama, Kaneko, Moriyoshi, Haramiishi, Watanabe and Iida, Transactions of the JSME (in Japanese), Vol.85, No.871 (2019)

以上の解析結果より，レイノルズ分解の定義に基づき，時間平均によりサイクル変動を含んだ平均流を求める 方法（時間平均法）と，ある 1 時刻における空間データのみを対象として任意フィルタ空サイズにより空間平均 する方法（空間平均法）を比較した結果，両者の平均流から得られた積分長さスケール $L$ がほぼ一致するような 平均条件でも，得られるサイクル変動流速パターンは異なった．そのため高速 PIV 計測を用いたサイクル変動評 価を行う場合，時間平均法による平均流の周波数変動と，空間平均法による平均流の波数変動をそれぞれ解析す る必要がある．また，高速 PIV でない逐次 PIV 計測の場合には，時系列データが得られないことから時間平均法 を行うことができない，その場合，可変フィルタサイズ空間平均法を用いることで，流速レンジの問題はあるも のの時間平均法に近いベクトルマップを得ることができる.

また前述したとおり，時間平均法に使用したカットオフ周波数には任意性および回転数依存があると報告され ている. 今回は吸気〜圧縮端まで一定值を使用したが，吸気行程中と圧縮行程では流速のオーダが一桁近く違う ため, カットオフ周波数も変化してくるものと思われる.

\section{6. 結 言}

本研究では, 時系列粒子画像の PIV 解析結果に基づき, 筒内流動のサイクル変動を評価するための平均流の抽 出を，時間平均法および空間平均法により行い，各平均流の特性と差異を評価した．また，カットオフ周波数べ 一スで空間平均を行うための可変サイズ空間平均法を提案し, 時間平均と同様の平均流が得られるようにカット オフ周波数ベースの空間平均処理を行った。 得られた結果を以下に示寸.

1. 流体の特性を示す指標のひとつである積分長さスケール $L$ を各平均法で比較した結果, 時間平均法および可 変サイズ空間平均法では，吸気行程から圧縮上死点までの $L の$ 傾向は一致した，一方，固定サイズ空間平均 法では, 下死点以降で時間平均法とほぼ一致したが, 固定サイズ法における $L_{f u}$ は, TDC へ向けた減少を再 現できない課題があった．また，今回 19x 19 data のフィルタを使用することで，固定サイズ空間平均の $L$ を 時間平均の $L$ と一致させたが，フィルタ空サイズによって $L$ の絶対值は変化してしまう. そのため, 時間平 均を行うことが出来ない逐次 PIV 計測では, 固定サイズ空間平均法のフィルタ密サイズ選定は難しいため, 代わりに可変フィルタサイズ空間平均法が有効である.

2. 各平均流の 1 サイクル中のベクトルマップを比較したところ, 流速の高い吸気行程中では, 可変フィルタサ イズ法に要求されるフィルタ空サイズが PIV の計測範囲を超える場合があり, 平均流の結果も他の平均流に 比べ, 流速が低くなる結果となった. しかしながら, 下死点以降の流れパターンは時間平均流とほぼ一致し, 固定サイズ空間平均流では低流速域における平均化が過剩となった.

3. 平均流の周波数および波数スペクトルを比較したところ，可変フィルタサイズ空間平均は，固定サイズ空間 平均よりも波数スペクトルが時間平均流に近づく結果となった.

4.「平均流ーアンサンブル平均流」から求めたサイクル変動流速パターンの比較では, 平均流の比較と同様, 吸気行程中には制限があるものの，下死点以降では可変サイズ空間平均法の結果は時間平均法とほぼ一致し， 固定サイズ空間平均法の場合, 小さな渦構造や流れの境界面が過剰に平均された.

\section{文献}

Druault, P., Guibert, P. and Alizon, F., Use of proper orthogonal decomposition for time interpolation from PIV data -application to the cycle-to-cycle variation analysis of in-cylinder engine flows -, Experimental in Fluids, Vol. 39, Issue 6 (2005), pp.1009-1023.

Fansler, T. and French, D., Cycle-resolved laser-velocimetry measurements in a reentrant-bowl-in-piston engine, SAE Technical Paper (1988), Paper No.880377.

Fraser, R. and Bracco, F., Cycle-resolved LDV integral length scale measurements in an I.C. engine, SAE Technical Paper (1988), Paper No.880381.

浜本嘉輔, 冨田栄二, 章忠, 栗城洋, 片岡義弘, エンジンシリンダ内乱流の計測（ディジタルフィルタによる平 均流と乱れの分離)，日本機械学会論文集 B 編，Vol.58, No.550 (1992), pp.1969-1974. 
日野幹雄, 流体力学 (1992), 朝倉書店.

Hokimoto, S., Kuboyama, T., Moriyoshi, Y., Iida, M. and Watanabe, T., Analyses of cycle-to-cycle variation of combustion and in-cylinder flow in a port injection gasoline engine using PIV and PLIF techniques, SAE Technical Paper (2017), Paper No.2017-01-2213.

Iijima, T. and Bracco, F., LDV measurements in an engine with square and circular piston cups, SAE Technical Paper (1987), Paper No.872073.

神本武征，八木田幹，森吉泰生，小林治樹，盛田英夫，透明シリンダエンジンによるシリンダ内空気流動に関す る研究，日本機械学会論文集 B 編, Vol.53, No.492 (1987), pp.2686-2693.

Keane, D. R. and Adrian, J., R., Optimization of particle image velocimeters : II multiple pulsed systems, Measurement Science and Technology, Vol.2 (1991), pp.963-974.

西原美一, メスバウアー・スペクトラムのコンピュータによる解析, 固体物理, Vol.11 (1976), pp.315-321.

Müller, R. H. S., Böhm, B., Gleißner, M., Grzeszik, R., Arndt, S. and Dreizler, A., Flow field measurement in an optically accessible, direct-injection spray-guided internal combustion engine using high-speed PIV, Experimental in Fluids, Vol. 48, Issue 2 (2010), pp.281-290.

小保方富夫, Bopp, S. and Tropea, C., 2 点相関測定用アダプタ付き光ファイバ LDA プローブ，日本機械学会論文集 B 編，Vol.55, No.513 (1989), pp.1490-1493.

大倉康裕，樋口和哉，浦田泰弘，染矢聡，店橋護，高速 PIV によるエンジン燃焼室の乱流計測，日本機械学会論 文集 B 編，Vol.79, No.806 (2013), pp.319-332.

大谷英男, 森吉泰生, 八木田幹, 神本武征, 圧縮行程中のシリンダ内乱れの減衰と生成に及ぼすスワールの影響 : 空間相関法による乱れスケールの LDV 測定，日本機械学会論文集 B 編, Vol.56, No.530 (1990), pp.3173-3180.

小沢慎治，ディジタル信号処理 (1979), 実教出版.

Reuss, L. D., Cyclic variability of large-scale turbulent structures in directed and undirected IC engine flows, SAE Technical paper (2000), Paper No.2000-01-0246.

Tennekes, H. and Lumley, J. H., A first course in turbulence (1972), The MIT Press.

可視化情報学会, PIV ハンドブック，第 1 版第 4 刷発行 (2013), 森北出版.

可視化情報学会，第 20 回可視化フロンティア「PIV 講習会 2015 (大阪)」(2015).

\section{References}

Druault, P., Guibert, P. and Alizon, F., Use of proper orthogonal decomposition for time interpolation from PIV data -application to the cycle-to-cycle variation analysis of in-cylinder engine flows -, Experimental in Fluids, Vol. 39, Issue 6 (2005), pp.1009-1023.

Fansler, T. and French, D., Cycle-resolved laser-velocimetry measurements in a reentrant-bowl-in-piston engine, SAE Technical Paper (1988), Paper No.880377.

Fraser, R. and Bracco, F., Cycle-resolved LDV integral length scale measurements in an I.C. engine, SAE Technical Paper (1988), Paper No.880381.

Hamamoto, Y., Tomita, E., Zhang, Z., Kurii, H. and Kataoka, Y., Measurement of turbulent flow in an engine cylinder (separation of mean velocity and turbulence by digital filter method), Transactions of the Japan Society of Mechanical Engineers, Series B, Vol.58, No.550 (1992), pp.1969-1974 (in Japanese).

Hino, M., Fluid dynamics (1992), Asakura Publishing Co., Ltd. (in Japanese).

Hokimoto, S., Kuboyama, T., Moriyoshi, Y., Iida, M. and Watanabe, T., Analyses of cycle-to-cycle variation of combustion and in-cylinder flow in a port injection gasoline engine using PIV and PLIF techniques, SAE Technical Paper (2017), Paper No.2017-01-2213.

Iijima, T. and Bracco, F., LDV measurements in an engine with square and circular piston cups, SAE Technical Paper (1987), Paper No.872073.

Kamimoto, T., Yagita, M., Moriyoshi, Y., Kobayashi, N. and Morita, H., An experimental study of in-cylinder air flow with a transparent cylinder engine, Transactions of the Japan Society of Mechanical Engineers, Series B, Vol.53, No.492 (1987), pp.2686-2693 (in Japanese).

Keane, D. R. and Adrian, J., R., Optimization of particle image velocimeters : II multiple pulsed systems, Measurement Science and Technology, Vol.2 (1991), pp.963-974.

Nishihara, Y., Computational analysis of Mössbauer spectrum, Solid state physics, Vol.11 (1976), pp.315-321 (in Japanese). 
Müller, R. H. S., Böhm, B., Gleißner, M., Grzeszik, R., Arndt, S. and Dreizler, A., Flow field measurement in an optically accessible, direct-injection spray-guided internal combustion engine using high-speed PIV, Experimental in Fluids, Vol. 48, Issue 2 (2010), pp.281-290.

Obokata, T., Bopp, S. and Tropea, C., LDA fiber-optic probe with adapter for two-point spatial velocity correlations, Transactions of the Japan Society of Mechanical Engineers, Series B, Vol.55, No.513 (1989), pp.1490-1493 (in Japanese).

Okura, Y., Higuchi, K., Urata, Y., Someya, S. and Tanahashi, M., Measurement of in-cylinder turbulence in an internal combustion engine using high speed particle image velocimetry, Transactions of the Japan Society of Mechanical Engineers, Series B, Vol.79, No.806 (2013), pp.319-332 (in Japanese).

Otani, H., Moriyoshi, Y., Yagita, M. and Kamimoto, T., The effect of swirl on the decay and generation of in-cylinder turbulence during the compression stroke (LDV measurement of turbulence length scales using the spatial correlation method), Transactions of the Japan Society of Mechanical Engineers, Series B, Vol.56, No.530 (1990), pp.3173-3180 (in Japanese).

Ozawa, S., Digital signal processing (1979), Jikkyo Shuppan Co., Ltd (in Japanese).

Reuss, L. D., Cyclic variability of large-scale turbulent structures in directed and undirected IC engine flows, SAE Technical paper (2000), Paper No.2000-01-0246.

Tennekes, H. and Lumley, J. H., A first course in turbulence (1972), The MIT Press.

The Visualization Society of Japan, PIV handbook, The first edition issued 4th Printing (2013), Morikita Publishing Co., Ltd (in Japanese).

The Visualization Society of Japan, The $20^{\text {th }}$ Visualization frontier 「Training session of PIV 2015 (Osaka)」 (2015) (in Japanese). 